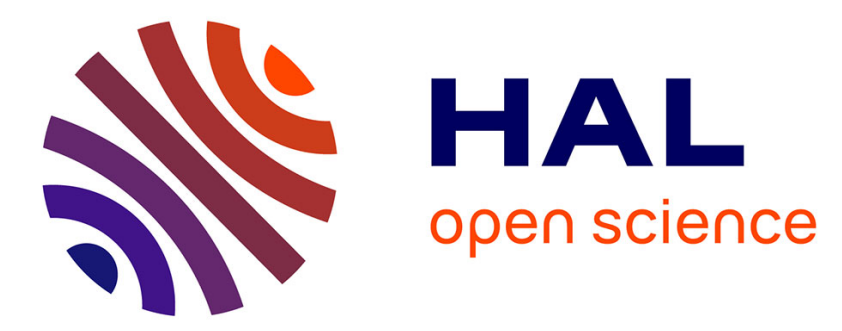

\title{
A framework for designing multi-functional agricultural landscapes: Application to Guadeloupe Island
}

Pierre Chopin, Jean-Marc Blazy, Loic Guinde, Jacques Wéry, Thierry Doré

\section{To cite this version:}

Pierre Chopin, Jean-Marc Blazy, Loic Guinde, Jacques Wéry, Thierry Doré. A framework for designing multi-functional agricultural landscapes: Application to Guadeloupe Island. Agricultural Systems, 2017, 157, pp.316-329. 10.1016/j.agsy.2016.10.003 . hal-01506530

\section{HAL Id: hal-01506530 \\ https://hal.science/hal-01506530}

Submitted on 27 Sep 2019

HAL is a multi-disciplinary open access archive for the deposit and dissemination of scientific research documents, whether they are published or not. The documents may come from teaching and research institutions in France or abroad, or from public or private research centers.
L'archive ouverte pluridisciplinaire HAL, est destinée au dépôt et à la diffusion de documents scientifiques de niveau recherche, publiés ou non, émanant des établissements d'enseignement et de recherche français ou étrangers, des laboratoires publics ou privés.

\section{다(1)(2)}

Distributed under a Creative Commons Attribution - ShareAlikel 4.0 International 
Doi: 10.1016/j.agsy.2016.10.003

2 Chopin, P., Blazy, J.-M., Guindé, L., Wery, J., Doré, T., 2017. A framework for

3 designing multifunctional agricultural landscapes: application to Guadeloupe Island. Agricultural

4 Systems 157, 316-329.

5

6 Title: A framework for designing multi-functional agricultural landscapes: Application to Guadeloupe 7 Island

9 Authors name: Pierre Chopin ${ }^{* a}$, Jean-Marc Blazy ${ }^{a}$, Loïc Guindé a , Jacques Wery ${ }^{\mathrm{b}}$, Thierry Doré ${ }^{\mathrm{c}}$,

10 e-mail of the corresponding author: pierre.chopin@ antilles.inra.fr

11 Affiliations:

12 a INRA, UR1321 ASTRO Agrosystèmes tropicaux, F-97170 Petit-Bourg (Guadeloupe), France

13 b SupAgro, UMR System, 2 place Pierre Viala, 34060 Montpellier Cedex 2, France

$14{ }^{\mathrm{c}}$ UMR Agronomie INRA, AgroParisTech, Universite Paris-Saclay, 78850 Thiverval-Grignon, France

16 Abstract

17 To improve agriculture faced with regional sustainability issues, agricultural landscapes providing a diversity and high level of ecosystem services are necessary. We have developed and tested the MOSAICA-f framework to build innovative multi-functional agricultural

20 landscapes that can consider explicitly: 1) the performance of cropping systems at the field

21 scale, 2) farmers' decision processes on the adoption of cropping systems, and 3) possible

22 scenarios for innovations and policy changes at the regional scale. This framework is based on

23 a scenario approach that encompasses normative, exploratory and optimized scenarios to

24 assess the relevance of combinations of new agricultural policies, changes to the external 25 context (market and regulations) and innovations in cropping systems. The impacts of these

26 changes on sustainability issues are simulated using the regional bioeconomic model

27 MOSAICA for farmers' decision processes regarding the adoption of cropping systems at the 28 field scale throughout a region. Applied in Guadeloupe (French West Indies), the MOSAICA- 
$29 \mathrm{f}$ framework enabled the design of a scenario increasing agricultural added value, food and

30 energy self-sufficiency, employment and the quality of water bodies and reducing greenhouse

31 gas emissions. This sustainable scenario combines new cropping systems tuned to farm types

32 with a reorientation of subsidies, an increased workforce and banning food crop production on

33 polluted soils. It can be used to understand the potential contribution of agriculture to

34 sustainability issues and to help local decision makers define policies that will account for the

35 spatial diversities of farms and fields in a landscape. Beyond the design of such a win-win

36 scenario, MOSAICA-f has revealed trade-offs in the provision of services by agriculture.

37

38 Highlights:

39 - We propose a modelling framework to aid the design of multi-functional landscapes

40 - The framework is based on a scenario approach coupled with an optimization model

41 - Normative, optimized, exploratory scenarios with multiple innovations are combined

42 - The framework is applied in Guadeloupe to design a sustainable scenario

43 - This framework can be used to provide information on possible futures of agriculture 
45 Agricultural landscapes account for one third of the land used by humans worldwide (FAOSTAT 2008). While agriculture has constantly increased food production, it is

47 responsible for other positive and negative environmental, economic and social impacts at the 48 global and local scales (Tilman et al., 2002). Although agriculture can ensure the production 49 of food, energy, materials and services for society (including the alleviation of poverty),

50 agriculture faces several sustainability problems, such as climate change and water and soil 51 pollution. The ability of agriculture to provide multiple services in a sustainable manner is 52 therefore being questioned (Klapwijk et al., 2014).

54 Agronomists have been designing new agricultural systems at the field and farm scales in 55 order to improve sustainability. However, the design of innovative agricultural systems at 56 these scales has certain limitations when addressing regional and global issues. For instance,

57 at the field scale, some cropping systems may fail to respond to sustainability issues defined 58 at the regional scale because of the low scaling integration and spatial heterogeneity at the 59 regional scale (Dale et al., 2013). Agronomists must therefore integrate a landscape 60 perspective when designing new agricultural systems adapted to local regions, and when 61 addressing sustainability challenges at the regional scale (Dale et al., 2013, Benoit et al., 62 2012). The design of such systems at the regional scale will result in new crop compositions 63 and organizations in landscapes that supply different ecosystem services (Castellazzi et al., 64 2010; Benoit et al., 2012; Schaller et al., 2012).

65

66 To determine whether a particular combination of factors such as agricultural policies (e.g.

67 changes to subsidies, bans on certain inputs), the social context of agriculture (e.g. new 68 markets) and the characteristics of cropping systems (e.g. new crops, new management, etc.) 
can drive agricultural change towards sustainability or have unexpected adverse outcomes, a

70 scenario analysis using an integrated agricultural landscape model is required (Wei et al.,

71 2009; Carmichael et al., 2004). In this case, an integrated model refers to one that includes

72 different spatial scales in the decision-making processes of farmers and relative to different

73 sustainability domains. The "drivers of change" represent potential causes of modifications to

74 the characteristics of farming systems and their combinations at the landscape level, which

75 will induce changes to the degree of sustainability that can be assessed using indicators

76 (Florin et al., 2013).

77

78 Agricultural science has already used scenario analysis coupled with integrated models to 79 analyse a wide range of sustainability issues relative to agricultural systems (Heckelei and 80 Britz, 2001; Kropff et al., 2001; Van Ittersum and Donatelli, 2003; Arfini, 2005; Verburg et 81 al., 2006; Bryan et al., 2011). However, the scenarios implemented in model-based landscape

82 frameworks tend to focus on a given type of scenario, based either on exploratory "what-if 83 scenarios" (Therond et al., 2009) or on the optimization of other indicators in the systems 84 (Hengsdijk and Van ittersum, 2002 ; Groot et al., 2007) in order to determine targeted outputs 85 for different objectives. These studies do not satisfactorily combine the different types of 86 scenarios necessary to understand the functioning of agricultural systems and their impacts at 87 a regional scale.

89 Moreover, some of these studies do no account for interactions between scales when trying to 90 identify the factors driving spatial dynamics (Houet et al., 2014). Several modelling 91 frameworks do not integrate the regional scale when assessing the services provided by 92 farming systems (Janssen and van Ittersum, 2007; Riesgo and Gomez-Limon, 2006; Parra93 López et al., 2008) while others take no account of the field scale (Schönhart et al., 2011). 
94 Model-based frameworks based on bioeconomic models are seldom spatially explicit with

95 regards to impact assessments of cropping systems due to a lack of information on field and

96 farm locations (van Ittersum et al., 2008; Delmotte et al., 2013), and their impact assessments

97 are not spatially located within an area of study (Meyer, 2007; Veysset et al., 2005; Gafsi et

98 al., 2006; Van Ittersum et al., 2008; see the SEAMLESS project at http://www.seamless-

99 ip.org/).

100

101 Chopin et al. (2015a) presented the MOSAICA regional bio-economic model and an example

102 of its application for scenario design in Guadeloupe, based on a preliminary characterization

103 of the diversity of farming systems (Chopin et al., 2015b). In the present paper, we propose a

104 methodological framework for the design of scenarios for landscape evolution using this bio-

105 economic model. This framework, called MOSAICA-f aims to build innovative multi-

106 functional agricultural landscapes. This enables the representation of agricultural landscape

107 changes under different drivers and assessment of their contributions to sustainable

108 development at the regional level. The finality of the framework is to: i) gain step-by-step

109 knowledge regarding the possible futures of agricultural landscape organization, and ii)

110 identify the relevant changes to agricultural policies, the social context of agriculture and the

111 characteristics of cropping systems needed to build multi-functional agricultural landscapes. 


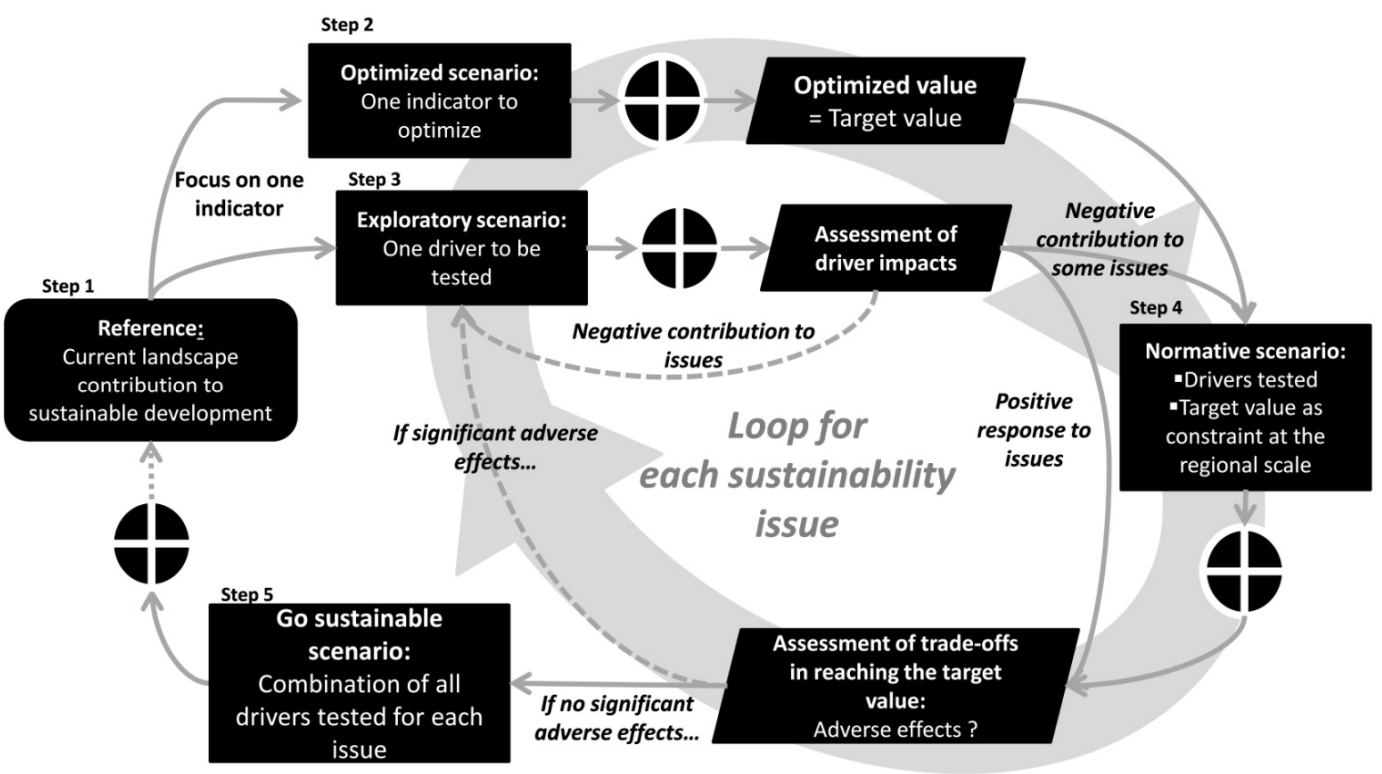

116 Figure 1 The MOSAICA-f framework for designing multi-functional landscapes. Steps are

117 represented by a pre modelling (square), a modelling (circle) and a post modelling phase

118 (parallelogram).

120 The framework presented in the paper aims to use the MOSAICA bioeconomic model in an

121 iterative manner in order to aid the building of multi-functional agricultural landscapes. The

122 model is applied in several steps involving different types of scenarios in order to understand

123 the potential for improvements to the landscape in terms of their contribution to regional

124 issues and to identify relevant drivers for change that will optimise their contribution. 


\begin{tabular}{|c|c|c|}
\hline \multirow[t]{2}{*}{ Variables to optimize } & \multicolumn{2}{|c|}{$\begin{array}{l}\text { Tested drivers } \\
\text { (changes in activity, equations and/or the geographical database) }\end{array}$} \\
\hline & No & Yes \\
\hline & Step 1: Reference mosaic & Step 3: Exploratory scenario \\
\hline $\begin{array}{l}\text { Optimization of the sum of } \\
\text { the farmer's utilities }\left(\mathrm{U}^{*}\right)\end{array}$ & $\begin{array}{l}\text { The reference values of the } \\
\text { indicator of interest, } Y_{\text {ref }} \text {, is } \\
\text { obtained } \\
\text { => Step } 2\end{array}$ & $\begin{array}{l}\text { Drivers tested to obtain the value of } \mathrm{Y}_{\text {expl }} \\
\text { - If } \mathrm{Y}_{\text {expl }}<\mathrm{Y}_{\text {ref }}=>\text { Change of driver } \\
\text { - if } \mathrm{Y}_{\text {expl }}>\mathrm{Y}_{\text {ref }} \text { and } \mathrm{Y}_{\text {expl }}<\mathrm{Y}^{*}=>\text { Step } 4 \\
\text { - If } \mathrm{Y}_{\text {expl }}>\mathrm{Y}^{*}=>\text { Use the Go sustainable } \\
\text { scenario }\end{array}$ \\
\hline & & $\begin{array}{l}\text { Step 5: "Go sustainable" scenario } \\
\text { Drivers from step } 4 \text { are combined here }\end{array}$ \\
\hline $\begin{array}{l}\text { Indicator providing } \\
\text { information of the response to } \\
\text { the sustainability issue of } \\
\text { interest (Y) }\end{array}$ & $\begin{array}{l}\text { Step 2: Optimized } \\
\text { scenario } \\
\text { Optimization of } \mathrm{Y} \\
\text { Target value } \mathrm{Y}^{*} \text { obtained } \\
\text { => Step } 3\end{array}$ & $\mathrm{Cos}$ \\
\hline & & Step 4: Normative scenario \\
\hline $\begin{array}{l}\text { Optimization of } \mathrm{Z} \text { with the } \\
\text { value of } \mathrm{Y}^{*} \text { to be reached }\end{array}$ & - & $\begin{array}{l}\text { If } Y_{\text {norm }}=Y^{*} \text { AND } W_{\text {norm }}, V_{\text {norm }}>0.8 * W_{\text {ref }} \\
V_{\text {ref }} \\
=>\text { Step } 5 \\
\text { Otherwise }=>\text { step } 3\end{array}$ \\
\hline
\end{tabular}

129 Table 1: Types of scenarios, their relationships within the framework and their

130 parameterization within the MOSAICA model. Y,W,V represent the values of different

131 indicators across the different phases of the framework: ref: at step 1 for the reference

132 calculation, *: at step 2 for optimized scenario, expl: at step 3 for exploratory scenario and norm:

133 at step 4 for normative scenario.

Our model-based framework consists of five steps (Figure 1), each combining three

framework components: scenario development, modelling and assessment. The loop between steps 2 and 4 is repeated for each sustainability indicator (Table 1). development using a reference mosaic of cropping systems. This mosaic is obtained from calibration of the model to the base year in our case study, which is explained in 

contribution of the reference mosaic to these issues, several indicators are used in the assessment (e.g. Y, W and V representing three given sustainability indicators). Cropping systems are located on each field of the region, and based on these locations, value for indicator $Y$. contribution of agriculture to sustainable development (e.g. Yref, Wref, Vref, etc.).

These references are then used to compare the contributions of mosaics from scenarios with the base year.

- The second step involves running optimized scenarios to reveal the potential to adapt cropping system mosaics in terms of their contribution to a set of sustainability issues. This potential represents the ability of the landscape to attain sustainability goals and is thereafter used as the "target value" for each sustainability indicator, such as the $\mathrm{Y}^{*}$

- The third step concerns the testing of several drivers of change, encompassing changes of agricultural policy, the social context and cropping system characteristics, in a series of exploratory scenarios. In this step, a single driver can be tested under exploratory scenarios or certain structurally linked drivers (e.g. both an increase in the price of food crops and limitations on production at a regional scale). In this step, we test each driver alone (e.g. one model run for the price increase in food crops and one model run for limitations on production at the regional scale) to identify whether they have any potential benefits in terms of contributing to targeted issues. Then, structurally linked drivers tested on the same sustainability issues are combined to improve the contribution of agriculture to this target issue. Drivers that improve the values of Yexpl of the Y indicator are compared with the Yref value from the reference 
mosaic (i.e., if Yexpl $>$ Yref and $\mathrm{Yexpl} \leq \mathrm{Y}^{*}$ in the case of maximization, the drivers are tested in step 4), while drivers that do not improve the contribution of the mosaic to the sustainability issue are removed from the analysis. If the Yexpl value obtained is higher than the optimized $\mathrm{Y}^{*}$ value, the fourth step is skipped and the drivers are drivers to different sustainability issues is only addressed in the fifth step. tested directly during the fifth step. Under these scenarios, the link between a specific driver and its contribution to the issues is examined, while the combination of several different drivers defined for each exploratory scenario, and the target values obtained under the optimized scenario, are set at the regional level. If reaching the target value of the indicator of interest is infeasible or adversely affects the contributions of agriculture to other sustainability issues, then other drivers are sought and the modellers must return to step 3 .

- The fifth step of the framework concerns testing of the relevant drivers previously identified and tested in steps 3 and 4 for each sustainability issue, that are here combined in a "Go sustainable" scenario. The agricultural landscape which best responds to this scenario is assessed, and indicator values are compared to the references. If the results are not satisfactory, iteration can be performed to restart the selection of drivers of change using either new drivers or new values associated with each driver (e.g. change in the value of prices for local production). If the cropping system mosaic thus generated is considered to be multi-functional (i.e., simultaneously reaching several sustainability targets), the results can be further analysed. This analysis encompasses observations of the spatial heterogeneity of the contribution to sustainability issues by analysing the indicators at different spatial scales (Figure 2). 


\subsection{Three components for the scenario analysis}

192

193

194

195

196

197

198

199

200

2.2.1 Scenario development (pre-modelling component)

The definition of several scenarios is the pre-modelling component in a model-based integrated assessment framework (Therond et al., 2009), which implies that the model must be parameterized using a new set of parameters for each scenario in order to assess the response of an agricultural landscape and its contribution to sustainability issues at the regional scale.

In our framework, the MOSAICA model is used for different types of scenarios to represent the response to the mosaics of cropping systems (Figure 1). Normative, optimized, or exploratory approaches can be used to design several types of scenarios. Thus different declinations of scenarios are used within our framework to compose an itinerary for cropping system mosaic design.

- Optimized scenarios: This scenario helps to determine the optimal value of a given indicator, which provides information regarding the contributions of agriculture to a related sustainability issue. The optimized value represents a "target value", i.e., a sustainability value to be attained by the cropping system mosaic in order to obtain the most sustainable state of the system considering this sustainability domain.

- Exploratory scenarios: The exploratory approach ("what if") is used to explore what will happen when changes in agricultural policy, the social context and cropping system characteristics impact the choices of farmers and therefore the cropping system mosaic (Borjeson et al., 2006; Van Notten et al., 2003). Exploratory "what-if" scenarios can answer the question "what will happen under certain new conditions?". They are helpful when selecting a set of new agricultural policies, changes in social 
context and cropping system characteristics to meet the target values defined previously, thereby improving the contribution of the cropping system mosaic to sustainability issues. These changes may be: i) changes at the field level, such as enabling access to irrigation; ii) the introduction of new cropping systems defined from experimental trials or expert knowledge; iii) changes to farm resources; iv) the modification of policy regimes, and v) changes in markets, such as prices and quotas.

- Normative scenarios: The normative approach ("what for") targets a set of indicator values to obtain the desired impacts of the cropping system mosaic, and it provides information regarding the contributions of the mosaics to this set of sustainability issues. Using the model in a normative way helps to determine whether the change tested previously with respect to agricultural policy, the social context and cropping system characteristics can help agriculture to attain its target and to predict the effects of achieving this target value on other sustainability issues. 


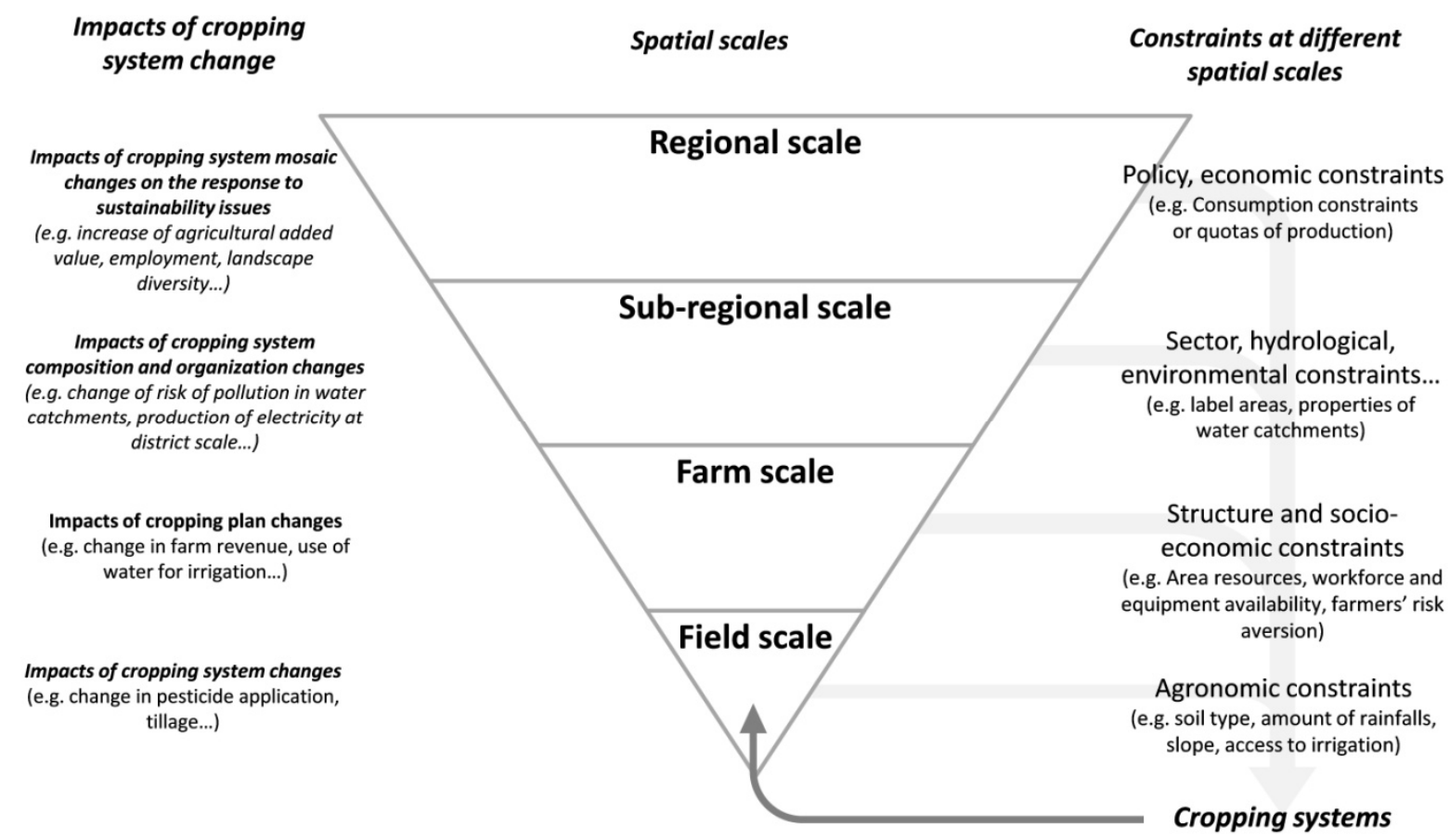

233 Figure 2 Inter-relationships of spatial scales in the adoption of cropping systems at the field

234 scale and the impacts of cropping system management at different spatial scales

The scenarios defined during the pre-modelling component were run using the MOSAICA regional bioeconomic model (Chopin et al., 2015b). This scenario simulates the decision processes of farmers in terms of adopting activities by linking them with a set of bioeconomic parameters (frequently referred to as technical coefficients) that drive these decisions (Janssen and van Ittersum, 2007). MOSAICA can be used for the ex ante assessment of the impacts of policies and technological, agronomic or economic changes,

242 amongst others (Janssen and van Ittersum, 2007; Belhouchette et al., 2011; van Ittersum et al., 243 2008; Louhichi et al., 2010). Farmers' choices concern the allocation of one or several 244 activities a, that represent cropping systems, to field $\mathrm{p}$. The simulation of farmers' choices is 245 achieved by optimizing the sum of the farmers' utilities $U$ (Equation 1) or by optimizing other 
246 variables in the agricultural system. The model variable to be optimized is calculated within 247 the objective function.

$249 \quad M A X U=\sum_{F}\left(\sum_{P} \sum_{\mathrm{a}}\left[X_{a, p}\left(\bar{m}_{a}-\phi_{\mathrm{F}}\left(\mathrm{Z}_{\mathrm{a}}^{+}+\mathrm{Z}_{\mathrm{a}}^{-}\right)\right]\right.\right.$

$251 \bar{m}_{a}=\left(\bar{y}_{a} p r_{a}+\operatorname{subsidies}_{a}\right)-\operatorname{cost}_{a}$

253 Under exploratory and normative scenarios, the objective function is the sum of the farmers' 254 utilities. These utilities are the sum of the farmers' incomes minus the expected reduction in 255 income due to variability of the gross margin, this being more or less important depending on 256 the value of the risk aversion coefficient $\varnothing$ of farmers, and the positive and negative 257 variability, Z+ and Z-, respectively, of the gross margin of activity a (Equation 1). Farmers' 258 incomes are the sum of field gross margins calculated based on the average gross margin ma 259 of each activity a allocated to each farmer's fields $\mathrm{p}$. The gross margin ma is calculated based on a mean yield y, a price pr and a given level of variable cost "cost" (Equation 2). The levels

261 of variability depend on the yield and price variability of the crop produced by activity a in

262 the market and is determined using agro-economic expertise. The vector of decision variables, 263 which is the area covered by each activity a on field $p$ (farmers can choose one or more 264 cropping systems for the same field) is indicated by the symbol Xa,p. These activities are 265 allocated to each field on a farm and, therefore, to all fields in the landscape under this optimization process. The risk aversion coefficient $\varnothing$ is used as the calibration parameter and

267 is attributed to the farm type, which is obtained from the farm typology, depending on current 268 farming systems and assuming that each type of farmer has a specific aversion to economic 269 risk depending on the structure of his farm and on the cropping systems he uses. Farmers are 270 classified within a given type using a classification algorithm that is implemented under 
271 MOSAICA. In this algorithm, each farm is considered to remain within the same type or is

272 moved to another type in the simulated mosaics, depending on the activities selected by the

273 optimization process (Chopin et al., 2015a).

274

275 The process of assigning activities to fields recorded in a geographical database is driven by

276 several types of constraints that are implemented at different spatial scales (Figure 2; see also

277 Chopin et al. 2015a). For instance, at farm level, the amount of workforce available limits the

278 adoption of labour intensive cropping systems. This information for the process of allocating

279 activities is determined for each field within the geographical database. The simulated

280 allocation process is spatially explicit because cropping systems are allocated to a given field

281 within the map of the territory, based on the sets of equations implemented at different spatial 282 levels within the model.

284 Thus, by modifying the constraints at the different spatial scales, the database of field 285 characteristics (changes to field parameters; e.g., change of slope due to remodelling), the 286 nature and technical coefficients of the activities to be allocated to fields and the objective to 287 optimize can be used to modify the cropping systems chosen by the simulated farmers at the 288 field scale. These cropping system changes at the field scale reorganize farming systems at the 289 farm scale and, in fine, the regional cropping system mosaic. Next, modification of the 290 cropping system mosaics may modify the contribution of mosaics to sustainable development, 291 which is assessed in the post-modelling component of the framework.

293 Under optimized scenarios, the objective function in Equation 1 is replaced by the target 294 indicator, e.g. the production of energy for the sustainability issue "improving energy self295 sufficiency". The cropping system mosaics derived from an optimized scenario are obtained 
by maximization or minimization (depending on the desired direction of change) of the value of one indicator related to the sustainability issues (Table 1). The only modification of the model structure is replacement of the sum of the farmers' utilities in the objective function by

299 the indicator to be optimized. The field characteristics, activities and constraint equations of 300 the model are not modified in this type of scenario.

301 The cropping system mosaics obtained from exploratory scenarios in step 3 result from 302 optimizing the sum of the farmers' utilities and from modifying the activities, model constraint equations and/or field characteristics (Table 1).

304 Normative scenarios are parameterized in step 4 using the same drivers as those used in step 3 305 of the exploratory scenario and by implementing a constraint equation at the regional scale in 306 order to reach the "target value" obtained from the optimized scenario.

\subsubsection{Assessment of cropping system mosaics: post-modelling component}

The contributions of cropping system mosaics to the sustainable development of a region were assessed using a set of indicators at the regional scale and calculated during the postmodelling component of the framework. Firstly, sustainability issues were selected from a

312 review of the literature in the area of study. Secondly, interviews were carried out with 313 decision-makers. In our case study, 13 regional decision-makers completed and validated the 314 list of issues by means of a web-based survey. Thirdly, based on the sustainability issues 315 identified at the regional scale, several indicators were used to assess the contribution of 316 cropping system mosaics to these issues. These indicators could either be reused from 317 previously published work, could be scale changed from one given scale to another, or could 318 be newly designed when the issues highlighted are locally contextualized. For instance, some 319 papers provide a calculation of indicators at the landscape scale (Gerdessen and Pascucci 320 (2013); Walz (2015)) that can be reused to assess the consequences of agricultural landscape 
321 changes (Sepp and Bastian, 2007). Many indicators are available at the cropping system scale

322 (Sadok et al., 2008; Carof et al., 2013) and may change with a given procedure, such as

323

324 aggregation procedures (Ewert et al., 2011). Others are not available because some issues are specific to our study and need to be built using existing knowledge. This was the case in our study with respect to the "decrease food contamination due to chlordecone in soils" issue which has never been assessed using indicators. We therefore had to build an indicator based on existing knowledge relative to the contamination process of food crops by chlordecone pesticides.

These indicators are calculated based on parameters that describe cropping system externalities and on the characteristics of the fields to which they are allocated. Activities are described using technical coefficients that represent the externalities of the crop production process with diverse information, such as yield or pesticide and fertilizer use. Calculating indicators at the regional scale provides a spatially aggregated value, and the indicators can be spatialized within the territory to display variations in the contributions of the fields, farms and sub-regions within a territory in order to improve decision-making.

\section{Application of the MOSAICA-f framework in Guadeloupe}

\subsection{Characteristics of the study area}

The MOSAICA framework was tested in Guadeloupe, an island located in the Caribbean. This territory presents suitable conditions for implementing the framework for several reasons. First, due to its insularity, flows of agricultural products are recorded at both entrance to and exit from the territory (Agreste, 2011; INSEE, 2012). Second, Guadeloupe has to deal with many local issues that limit the economic, environmental and social sustainability of the 
territory and may be linked to agriculture. These issues include low food and energy self-

sufficiency, a high level of unemployment and a risk of pollution of water resources by pesticides (rivers and drinking-water abstractions) used for local consumption (PDRG, 2011). Another challenge is to "decrease food contamination due to chlordecone in soils".

Chlordecone is a remnant pesticide that was used between 1965 and 1993 on $15 \%$ of cultivated land in Guadeloupe (Tillieut and Cabidoche, 2006). The regular consumption of food crops grown on these polluted soils can provoke severe health problems such as prostate cancer (Multigner et al., 2010). Third, Guadeloupe is a small territory that covers $1600 \mathrm{~km}^{2}$ and includes a significant agricultural area of 31,300 hectares. Fourth, geographical data and statistical information on fields and farms in Guadeloupe, and knowledge regarding cropping system performances and farm functions, are available. This information describes the population of farmers and their activities. Finally, the region is heterogeneous, with rainy mountainous areas on volcanic soils and flat lands on dry calcic soils, which is of interest when testing the ability of the framework to account for biophysical and socio-economic variability.

\subsection{Adaptation of the MOSAICA model in Guadeloupe}

We explain our adaptation of the MOSAICA model that supports the proposed framework for Guadeloupe by briefly describing its principal elements for the simulation of multi-functional agricultural landscapes (Chopin et al., 2015b).

367 - The database on field characteristics obtained from the Agrigua association that gathers declarations of farmed land for subsidies, comprised 25,057 fields and includes biophysical and farm structure information represented by polygons covering 

Guadeloupe).

- We described 36 activities covering the eight main crops in Guadeloupe: sugar cane, banana, pasture, orchards, pineapple, plantain, crop-gardening and tubers, with different management strategies.

- Constraint equations were implemented at different spatial scales to constrain the adoption of activities allocated at the field scale. For instance, we implemented a set of equations linking the cropping systems to slope, field area, soil type and land tenure at production quotas and workforce resources were used as the primary constraints for the adoption of cropping systems. At the sub-regional scale, environmentally protected zones and geographically protected indications constrain the adoption of cropping systems. At the regional scale, we defined the maximum thresholds for limiting the quantities of crops produced (production quotas or overall local consumption from local production and importation).

- The farm typology used was described by Chopin et al. (2015a), in which eight types of farmers (orchard growers, banana growers, breeders, market gardeners, diversified cane-growers, diversified, mixed, specialized cane-growers) are defined using a classification algorithm that allocates each farm to one of the types after new cropping system mosaics are produced by simulation.

- The model was calibrated in Guadeloupe by allocating a risk aversion coefficient to each farm depending on its type under our farm typology. The model was considered to be valid because of the crop areas predicted by the reference mosaic, and because the areas calibrated at the regional, sub-regional, farm and field scales were similar (Chopin et al., 2015b). 


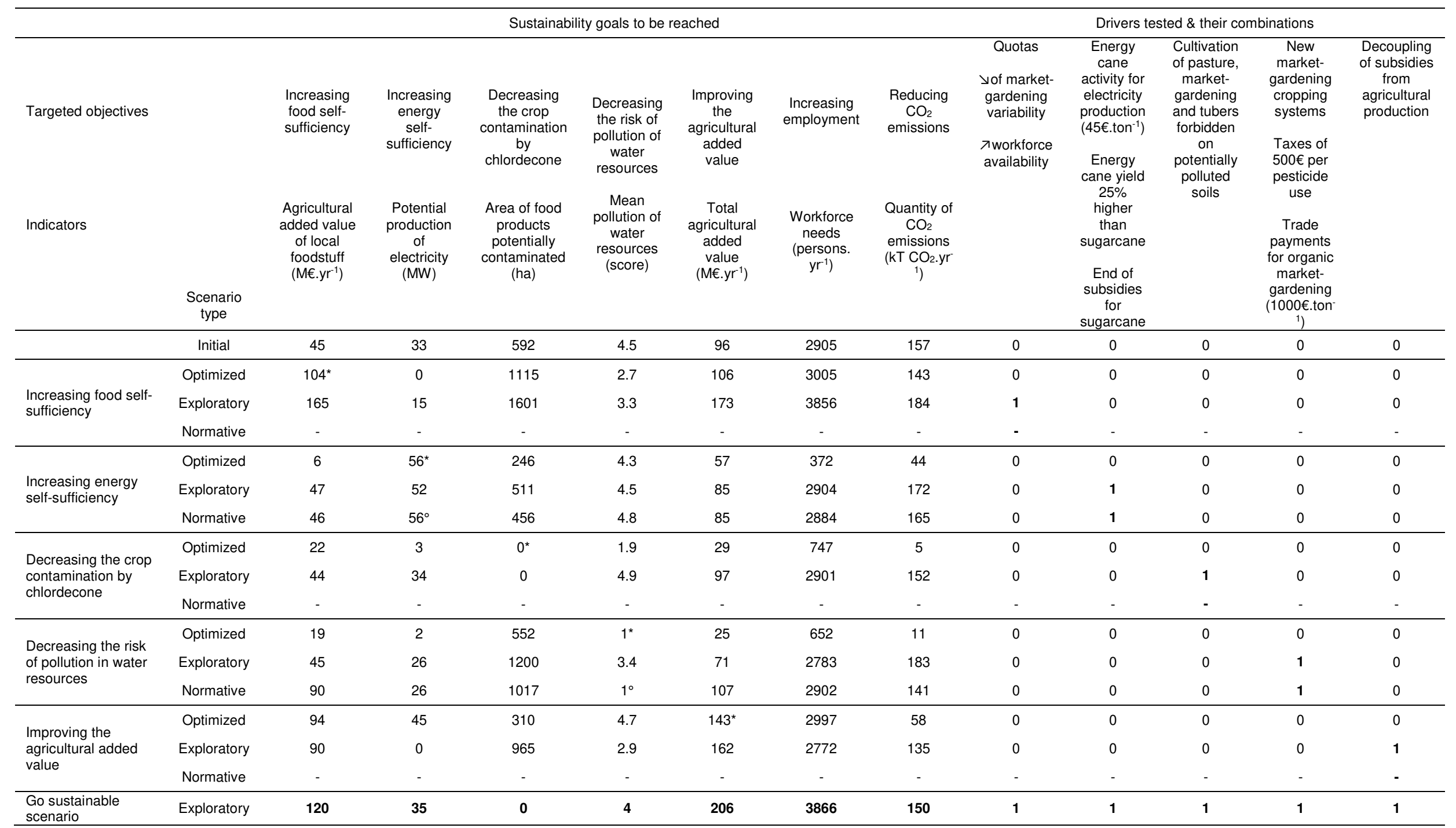

395 Table 2: Results from the scenario analysis in terms of the responses to local and global sustainability issues. Numbers with $*$ are optimized

396 values. 


\subsection{Step 1: Diagnosis of the reference contributions of agriculture to sustainable}

\section{development}

The sustainability goals for agriculture in Guadeloupe are to: i) increase crop production for local markets, ii) increase biomass production for electricity production, iii) decrease the risks of crop contamination by chlordecone, iv) limit the pollution of water resources, especially rivers and drinking-water sources, and v) improve the overall added value of agriculture. The provision of employment for crop management was also assessed because it is an important parameter of the farm model. However, employment was not included in the scenario analysis because the workforce cannot increase beyond the limits set for each farm type in the model. The contribution of agricultural systems to greenhouse gas emissions was also evaluated because it is a key component in efforts to mitigate climate change. Indicators were first of all calculated for the reference cropping system mosaics obtained from the calibration (Table 2).

\subsection{Step 2: Optimized scenarios}

Optimizing the current situation regarding the added value of local foodstuffs produced by agriculture (food self-sufficiency) resulted in a target value of 104 millions $€$ per year. This value was used as a target value. Under the second optimized scenario for energy selfsufficiency, we optimized electricity production and obtained a target value of 56 MW.yr-1. This scenario also reduced the number of employees required for crop management from 2905 to 372 persons. The risk of crop contamination by chlordecone reached a negligible value when local foodstuffs decreased from 45 to 6 million per year and employment decreased from 2902 to 747 persons. The risk of pollution of water resources was high in the diagnosis of the reference situation but decreased from 4.5 to 1 unit of the I-PHY indicator. However, major reductions in the achievements of other sustainability goals, such as employment, the agricultural added value of local foodstuffs and the potential production of 
electricity, were observed, with decreases from 2905 to 652 persons, 45 to 19 millions $€$ per year and 33 MW.yr-1 to 2 MW.yr-1, respectively. The overall agricultural added value increased from its reference level of 96 to 143 millions $€$ per year, and most sustainability issues improved, except for the risk of pollution of water resources, which increased from 4.5 to 4.7 units of the I-PHY indicator. These new optimized values were used as target values under the normative approach (step 4).

\subsection{Step 3: Exploratory scenarios}

Different drivers, agricultural policies, contextual social changes and new cropping system characteristics were all tested under the exploratory approach in step 3 to reach the target values identified in step 2 and presented in Table 1 . The exploratory scenarios tested here combined several types of possible changes, such as new policies, new biophysical contexts and agronomic innovations. Based on our knowledge of the region, under one exploratory scenario we were able to test several drivers for change linked by nature. For instance, in order to produce more local foodstuffs, education to achieve changes in diet towards more local food crops is needed (simulated with the deletion of production thresholds), alongside encouraging local production through agricultural policies such as subsidies. The impacts of these changes were assessed by running the model with the modifications of these activities, the geographical database and the equations defined at the different spatial scales.

1. The first exploratory scenario consisted of a combination of several changes, including increased market size at the regional scale (represented with regional thresholds in the model) for plantain, pineapple, and tubers at the regional scale, reduced variability of the gross margins of crops due to improved advice for local producers, an increase of 1000 in the workforce available at the regional scale and doubling of the overall availability of water for irrigation. These changes increased the generation of 
agricultural added value from local foodstuffs to 165 millions $€$ per year, which is higher than the previously obtained optimized value of 104 millions. These drivers were relevant for responding to this issue because they exceeded the objective set by the target value.

2. The second exploratory scenario was a combination of the introduction of energy cane for electricity production with a price of $45 €$.ton- 1 , a $25 \%$ increase in sugar cane yield potential, and the cessation of subsidies supporting sugar cane cultivation to increase the production of biomass for electricity production. These changes increased electricity production from $33 \mathrm{MW} . \mathrm{yr}-1$ in the reference mosaic to $52 \mathrm{MW} . \mathrm{yr}-1$ under the exploratory scenario, which is below the target value of $56 \mathrm{MW} . \mathrm{yr}-1$. A normative scenario was therefore necessary in step 4 to understand the possible effects of reaching the target value on the other sustainability goals.

3. The third exploratory scenario consisted of banning vegetable, pasture and tuber cultivation on soils potentially contaminated by chlordecone in order to decrease the risk of crop contamination. This ban was spatially targeted on the 3708 of the 25,057 fields in the region where the risk of soil contamination by chlordecone is significant. This ban was effective because the areas with potential risks of contamination of foodstuffs dropped from 592 ha in the reference cropping system mosaic to zero under the exploratory scenario. Banning market gardening and tuber production in highly chlordecone-contaminated zones was an efficient strategy for completely reducing the risks of crop contamination by chlordecone while maintaining the values of the others objectives near the values achieved in the reference state.

4. The fourth exploratory scenario consisted in introducing new organic cropping systems to decrease the risk of pollution of water resources by pesticides. The technical coefficients of these activities were defined using expert knowledge. The 
yield decreased by $50 \%$, the workforce requirement increased by $20 \%$ and prices rose by $25 \%$. Yield variability increased when compared with conventional cropping and market gardening. The cropping and market gardening systems were taxed at a rate of $500 €$ per point of treatment frequency index (TFI), based on their average TFI. Subsidies were provided to help commercialize the organic products, with a total of $1000 €$.ton- 1 of vegetables and fruits from these new organic cropping systems (POSEI, 2012). The "introduction of organic crop-gardening activities" and "the taxes on the use of pesticides" points in the exploratory scenario did not make it possible to reach the target value for the risk of pollution of water resources of approximately 1 . However, the decrease in this value from 4.5 to 3.5 was significant. A normative scenario also needs to be drawn in step 4 to reach the target value.

5. The fifth exploratory scenario was the end of POSEI ("Programme of specific options for isolation and insularity") payments towards banana and sugar cane and the decoupling of farm subsidies from agricultural production to improve the added value of agriculture. This scenario would enhance the agricultural added value of crop production devoted to the local market. The decoupling of subsidies was relevant because the agricultural added value increased from 96 millions $€$ per year in the reference mosaic to 162 millions $€$ per year under the exploratory scenario, which exceeded the optimized value in step 2 of 143 millions $€$ per year.

The drivers used for each scenario are described in Table 2.

\subsection{Step 4: Normative scenarios}

Normative scenarios were tested in step 4 to assess the potential of the mosaic to attain the target values for "increasing energy self-sufficiency" and "decreasing the risk of pesticide 
pollution of water resources" without significantly reducing the contributions of the cropping system mosaic to other sustainability domains.

Regarding energy self-sufficiency, the normative scenario was tested by optimizing the overall farmers' utilities under the constraint of producing at least $56 \mathrm{MW} . \mathrm{yr}-1$. This was feasible and produced acceptable results for the other sustainability domains when compared with the reference cropping system mosaic. The area of potentially contaminated products decreased from 592 to 456 ha. In parallel, the risk of pollution of water resources increased from 4.5 to 4.8 , and the agricultural added value decreased from 96 to 85 millions $€$ per year. Regarding the risk of pollution of water resources, the normative scenario successfully allowed the crop mosaic to reach the target value of 1 , which corresponds to a very low risk of this pollution. The agricultural added value of local food crops increased from 45 to 90 millions $€$ per year, while the overall agricultural added value increased from 96 to 107 millions $€$ per year. CO2 emissions decreased from 157 to $141 \mathrm{kt}$ equivalent $\mathrm{CO} 2 . \mathrm{yr}-1$. In parallel, the area of food products that was potentially contaminated due to chlordecone in soils increased from 552 ha to 1017 ha, and potential electricity production fell from 33 to 26 MW.yr-1.

We considered these drivers of change as being effective in reaching the set of target values when using the optimized scenario in step 2 because the average contribution to other issues increased by $8 \%$ for the "increase energy self-sufficiency" issue and only decreased by $3 \%$ for the "decrease of the risk of pollution of water resources" issue, which was below the $20 \%$ threshold set in the framework (Table 1).

All of the drivers tested under the exploratory scenarios helped to reach or exceed the target values fixed by the optimized scenarios. When the drivers did not reach these values, we noticed that reaching them under the normative scenarios had no significant negative side 
effects. Next, these drivers were combined in step 5 under a "Go sustainable" scenario, which reflects optimization of the overall farmers' utilities for the selected political, agronomic or external drivers of change.

\subsection{Step 5: Prototyping a "Go sustainable" scenario}

3.8.1 Improvements in the contributions of agriculture to sustainable development

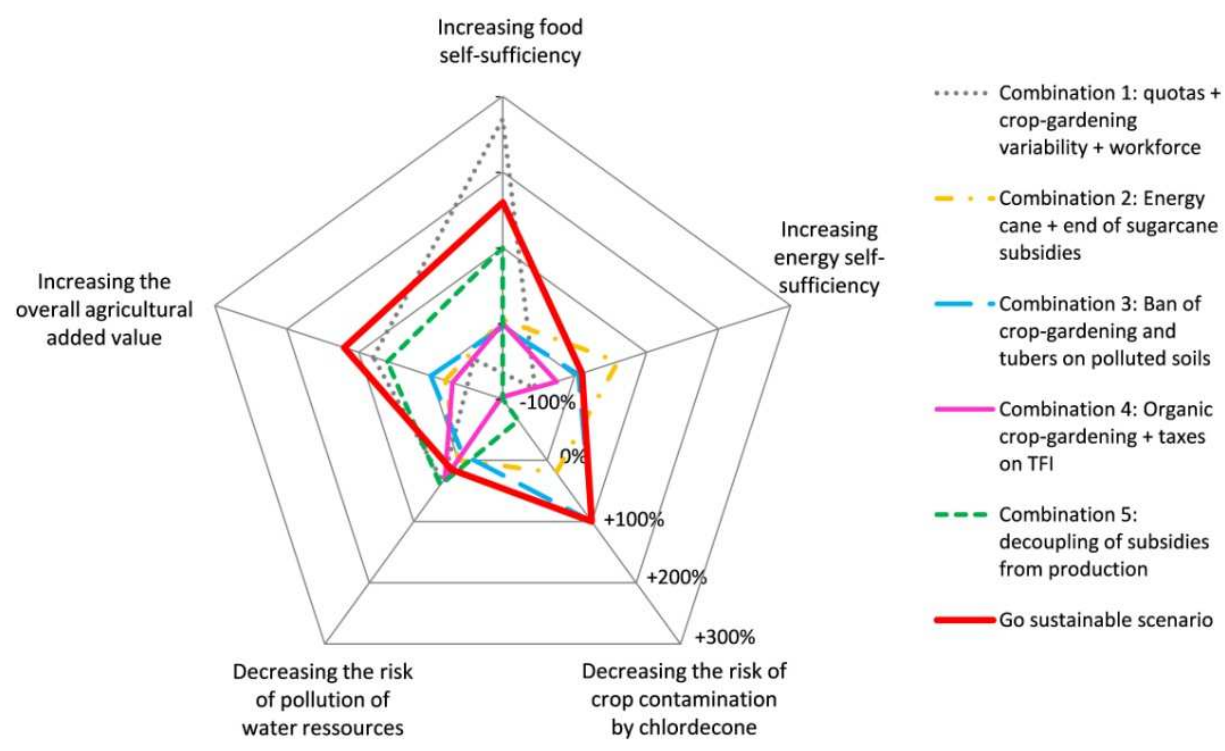

Figure 3 Evolution of the contributions of each mosaic from exploratory scenarios compared to the initial values from the current cropping systems mosaic assessed as deviations from the initial values. Positive deviational values are an improvement of the generated mosaic to respond to sustainability issues

This exploratory scenario revealed major improvements due to the contributions of cropping system mosaics to all sustainability issues in the analysis when compared to the reference situation (Table 2 and Figure 3). The agricultural added value of local production increased from 45 to 120 millions $€$ per year, electricity production increased from 33 to 35 MW.yr-1, the area at risk of crop contamination decreased from 592 to 0 ha, the risk of pollution of 

in the risk of crop contamination by chlordecone and improved energy self-sufficiency.

552

553 3.8.2 Spatial heterogeneity of the contributions of cropping system mosaics to sustainable 554 development in the territory 

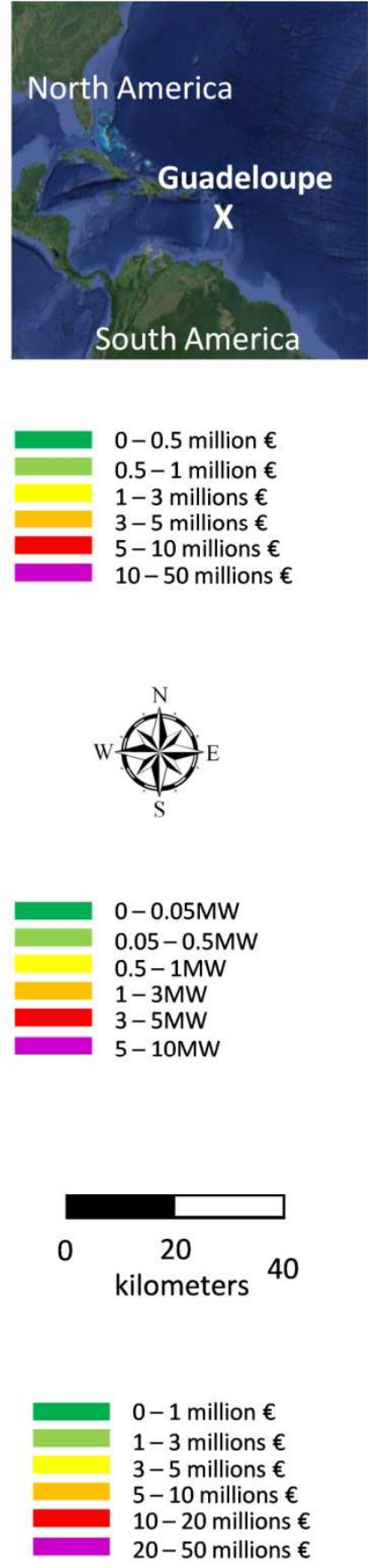

Figure 4 Comparison of the evolution of the contributions of cropping system mosaics to the increasing added value of agricultural from local food stuff (top) to the contributions to

558 electricity production (middle) and the production of added agricultural value (bottom)

559 between the current mosaic (on the left) and the "Go sustainable" scenario (on the right).

560 The contributions of the different cropping systems to sustainability issues can also be
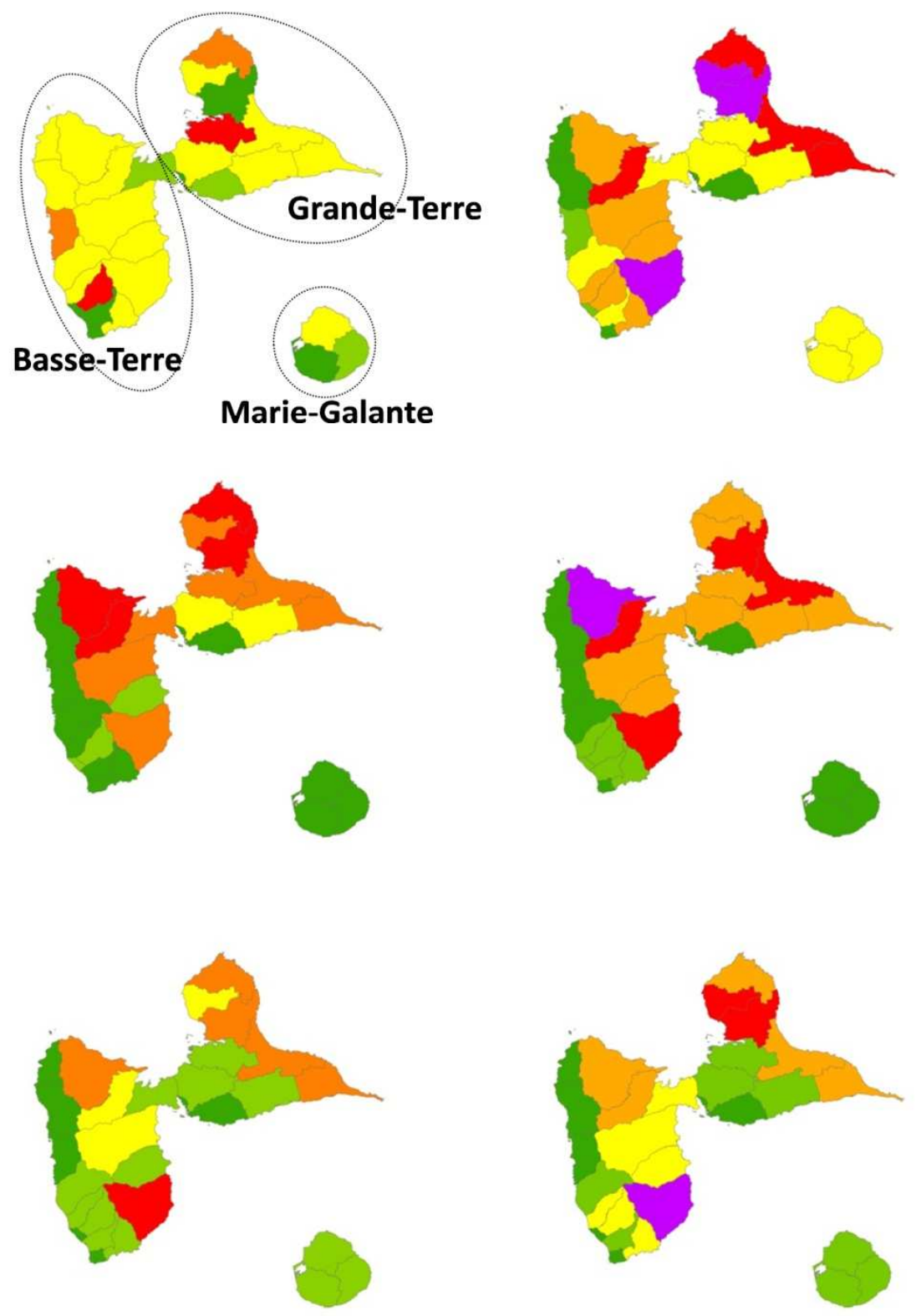
the spatial variations of the contributions of sub-regions to food and energy self-sufficiency and the increases in overall agricultural added value and agricultural added value from local foodstuffs. Using the same method, the spatial variability of the contributions of cropping system mosaics to local issues is displayed at the sub-regional and field scales in order to analyse reductions in risk of pollution of water resources and in the risk of food contamination (see Supplementary Materials - Figure A).

At the sub-regional scale, the production of agricultural added value from local foodstuffs increased in most sub-regions. The greatest increases were observed in the northern and eastern parts of Grand-Terre and in south-eastern Basse-Terre, due to increases in conventional and organic crop-gardening (Figure 4). Electricity production increased across the territory due to the replacement of sugar cane by energy cane, which is more efficient and more productive. As expected, the increase in overall agricultural added value was higher in northern Grande-Terre and southern Basse-Terre due to the expansion of market gardening in these zones.

As for decreasing the risk of pollution of water resources, we observed an evolution of the effects of pesticide application in rivers and drinking-water abstractions (Supplementary materials). In the reference cropping system mosaic, most rivers in south-western Basse-Terre are potentially polluted by the pesticides used for banana cultivation and intensive market crop-gardening/orchard production. The reduction in the risk of pollution of water resources in the scenario in southern Basse-Terre was important when banana and market cropgardening were replaced by less intensive cropping systems. The targeted reduction in the risk of crop contamination by chlordecone was attained, with all the area potentially contaminating crops in southern Basse-Terre being transformed into an area free of risk of contamination. This was due to the change from pasture in this zone to non-contaminating 
crop-gardening, including for instance tomatoes and cauliflowers (and not cucurbitaceae that are highly contaminated by chlordecone) or plantain (Cabidoche and Lesueur-Jannoyer, 2012).

\subsection{Analysis of modifications to the agricultural system under the "Go sustainable"} scenario

3.9.1 Cropping system changes

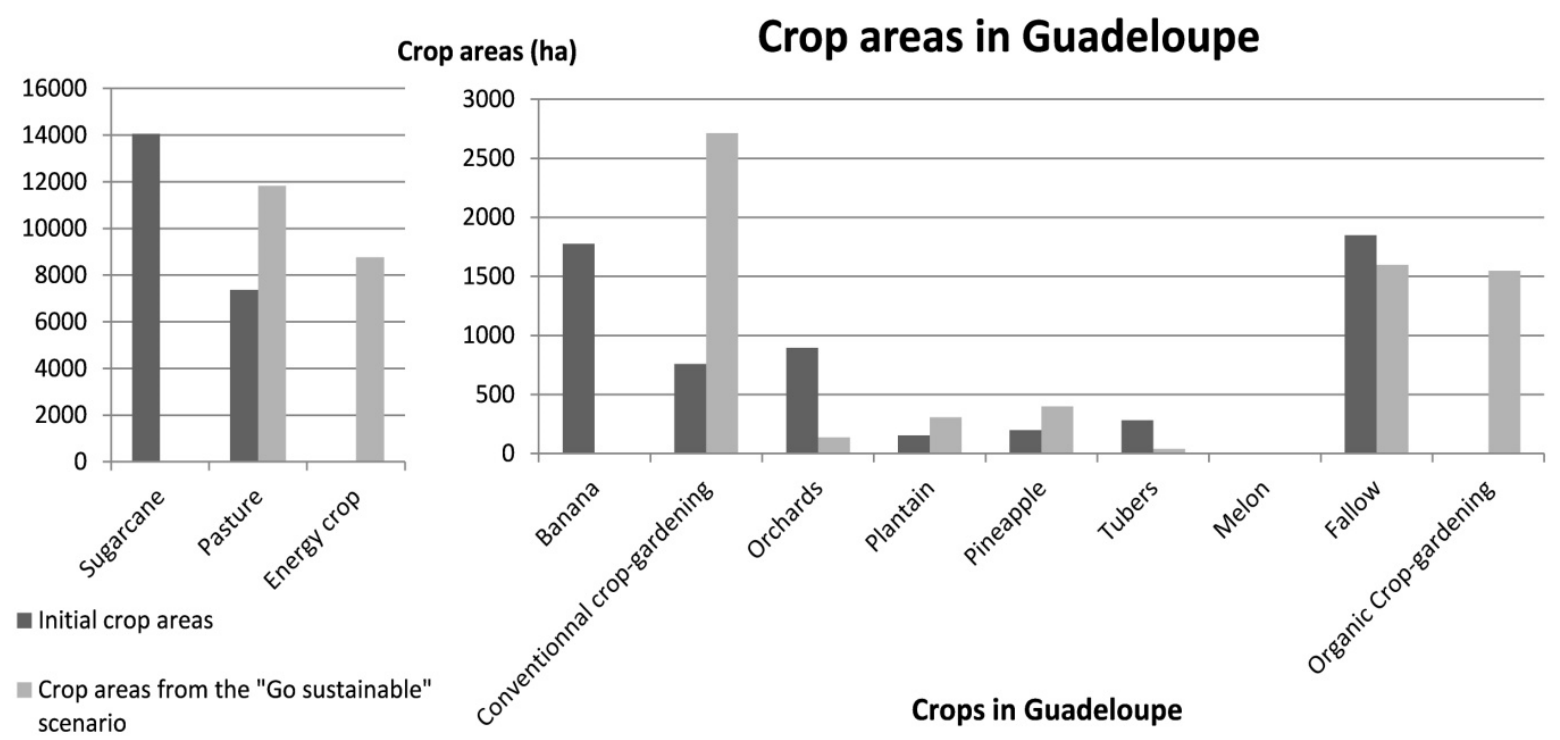

Figure 5 Evolution of the crop areas at the regional scale between the initial situation and the cropping system mosaics obtained in the "Go sustainable" scenario

The main trend for change was the disappearance of sugar cane and banana and an increase in crop-gardening and pasture and energy cane for electricity production (Figure 5). 


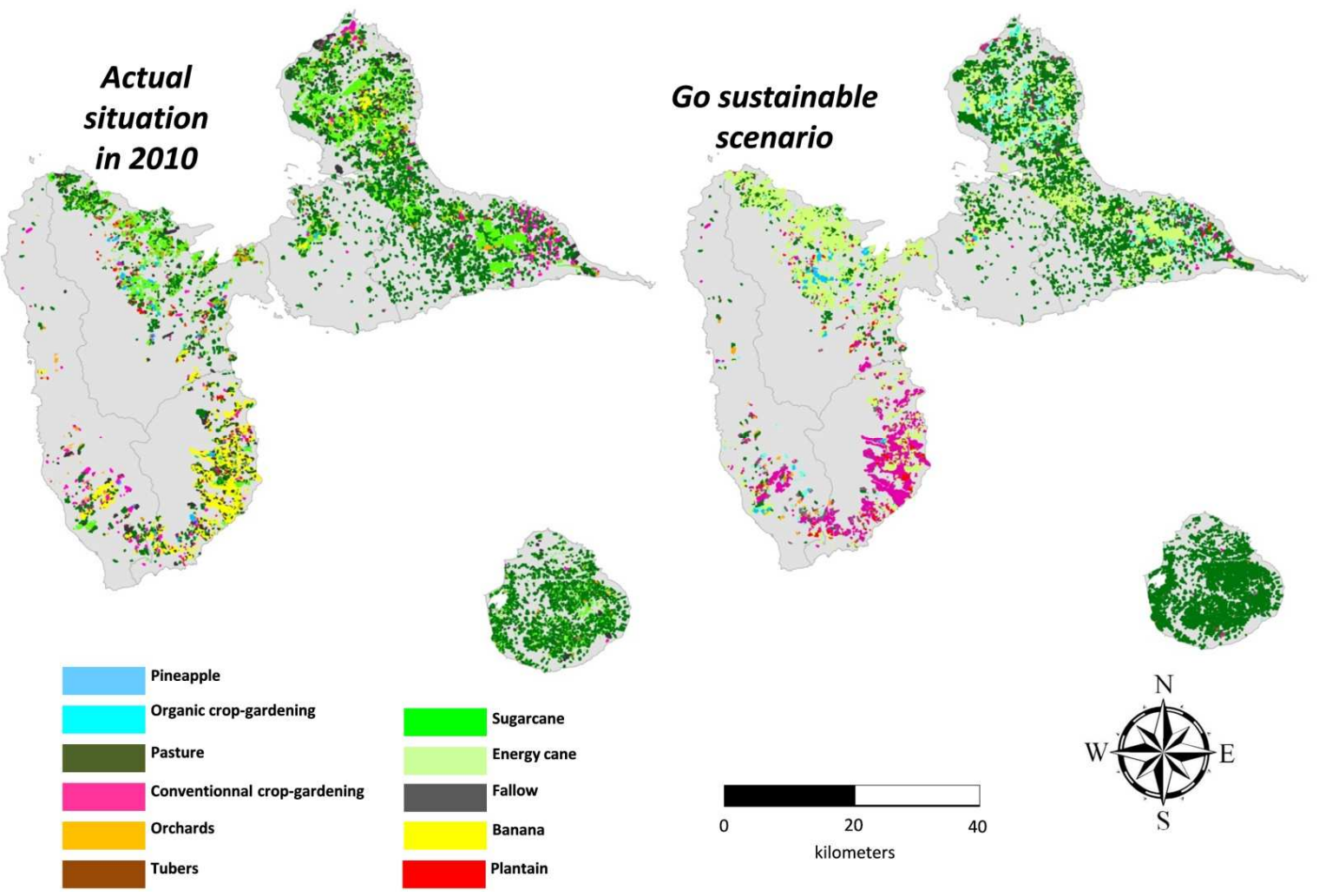

602 Figure 6 Evolution of the crop arrangement in Guadeloupe at the regional scale between the

603 initial situation and the cropping system mosaics from the "Go sustainable" scenario

The spatial arrangement of cropping systems changed within the territory as a result of the crop changes on farms (see Figure 6). This change mainly occurred in northern Grande-Terre with the emergence of organic crop gardening and in south-eastern Basse-Terre with the development of crop-gardening and plantain. The eastern part of Grande-Terre remained cultivated with conventional crop-gardening, but organic crop- gardening appeared in this zone, as did the cultivation of energy cane. In northern Basse-Terre, a high proportion of sugar cane was mainly replaced by energy cane, and the area of pineapple and conventional cropgardening at the border with south-eastern Basse-Terre increased. The south-western part of the island was turned into a sub region with more crop-gardening and plantain in replacement of banana for export. 


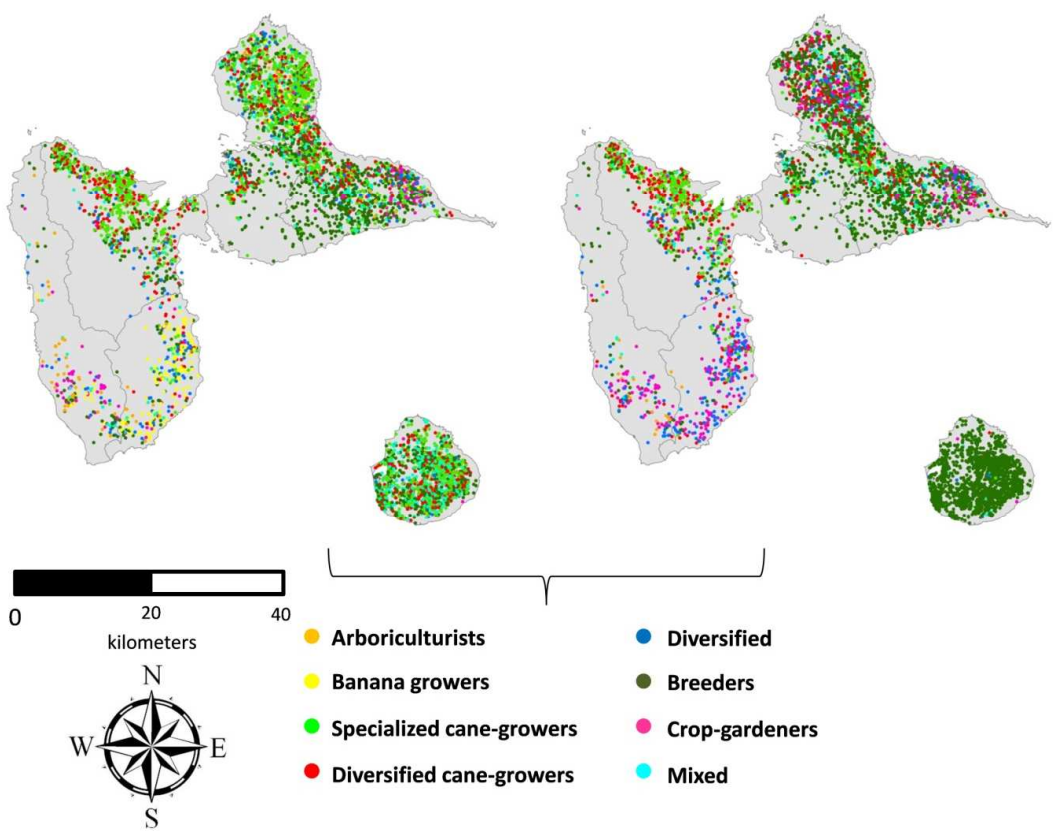

Main farm type transitions

Go sustainable mosaic

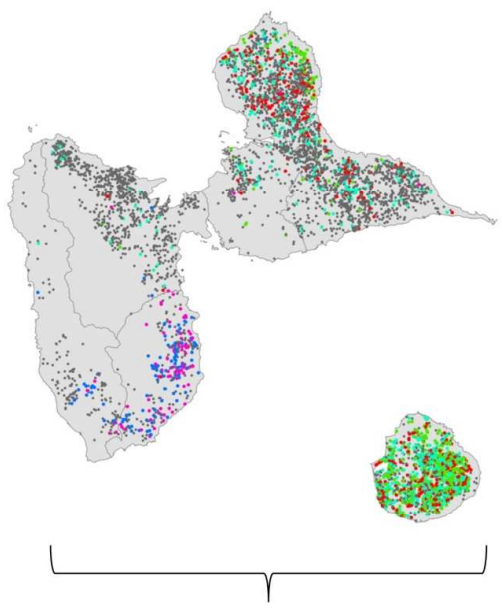

- From « banana growers " to " diversified "

- From « banana growers " to " crop-gardeners "

- From « mixed " to « breeders "

- From " Diversified cane-growers " to " breeders "

- From " specialized cane-growers " to " breeders "
617

Figure 7 Evolution of the farm types in Guadeloupe at the regional scale between the initial situation and the cropping system mosaics from the "Go sustainable" scenario

The changes in farm types are shown in Figure 7, and the trajectories of change are shown in Table 3 (see Supplementary materials - Figure B). The main trend was a change from mixed and specialized cane-growers towards livestock breeders. This was especially true in the Marie-Galante island, where under this scenario there is no industry for the production of electricity with energy cane (See Figure 7). However, a small proportion of cane-growers changed to crop-gardeners and to diversified cane-growers type, especially in northern and eastern Grande-Terre. 


\begin{tabular}{|c|c|c|c|c|c|c|c|c|c|}
\hline $\begin{array}{l}\text { Initial farm type / } \\
\text { farm types after } \\
\text { the "Go } \\
\text { sustainable" } \\
\text { scenario }\end{array}$ & Arboriculturists & $\begin{array}{l}\text { Banana } \\
\text { growers }\end{array}$ & $\begin{array}{l}\text { Specialized } \\
\text { cane- } \\
\text { growers }\end{array}$ & $\begin{array}{c}\text { Diversified } \\
\text { cane- } \\
\text { growers }\end{array}$ & Diversified & Breeders & $\begin{array}{l}\text { Crop- } \\
\text { gardeners }\end{array}$ & Mixed & $\begin{array}{c}\text { Initial } \\
\text { number } \\
\text { of } \\
\text { farms }\end{array}$ \\
\hline \multirow{2}{*}{ Arboriculturists } & 10 & 0 & 0 & 30 & 31 & 35 & 2 & 13 & \multirow{2}{*}{121} \\
\hline & $8 \%$ & $0 \%$ & $0 \%$ & $25 \%$ & $26 \%$ & $29 \%$ & $2 \%$ & $11 \%$ & \\
\hline \multirow{2}{*}{ Banana growers } & 1 & 0 & 0 & 3 & 80 & 5 & 106 & 10 & \multirow{2}{*}{205} \\
\hline & $0 \%$ & $0 \%$ & $0 \%$ & $1 \%$ & $39 \%$ & $2 \%$ & $52 \%$ & $5 \%$ & \\
\hline \multirow{2}{*}{$\begin{array}{r}\text { Specialized cane- } \\
\text { growers }\end{array}$} & 0 & 0 & 546 & 140 & 79 & 630 & 156 & 26 & \multirow{2}{*}{1577} \\
\hline & $0 \%$ & $0 \%$ & $35 \%$ & $9 \%$ & $5 \%$ & $40 \%$ & $10 \%$ & $2 \%$ & \\
\hline \multirow{2}{*}{$\begin{array}{r}\text { Diversified cane- } \\
\text { growers }\end{array}$} & 0 & 0 & 110 & 345 & 7 & 524 & 0 & 64 & \multirow{2}{*}{1050} \\
\hline & $0 \%$ & $0 \%$ & $10 \%$ & $33 \%$ & $1 \%$ & $50 \%$ & $0 \%$ & $6 \%$ & \\
\hline \multirow{2}{*}{ Diversified } & 0 & 0 & 5 & 49 & 101 & 78 & 29 & 24 & \multirow{2}{*}{286} \\
\hline & $0 \%$ & $0 \%$ & $2 \%$ & $17 \%$ & $35 \%$ & $27 \%$ & $10 \%$ & $8 \%$ & \\
\hline \multirow{2}{*}{ Breeders } & 6 & 0 & 12 & 14 & 10 & 1044 & 0 & 3 & \multirow{2}{*}{1089} \\
\hline & $1 \%$ & $0 \%$ & $1 \%$ & $1 \%$ & $1 \%$ & $96 \%$ & $0 \%$ & $0 \%$ & \\
\hline \multirow{2}{*}{ Crop-gardeners } & 0 & 0 & 0 & 0 & 4 & 0 & 150 & 0 & \multirow{2}{*}{154} \\
\hline & $0 \%$ & $0 \%$ & $0 \%$ & $0 \%$ & $3 \%$ & $0 \%$ & $97 \%$ & $0 \%$ & \\
\hline \multirow{2}{*}{ Mixed } & 3 & 0 & 3 & 8 & 8 & 654 & 0 & 178 & \multirow{2}{*}{854} \\
\hline & $0 \%$ & $0 \%$ & $0 \%$ & $1 \%$ & $1 \%$ & $77 \%$ & $0 \%$ & $21 \%$ & \\
\hline $\begin{array}{l}\text { Number of farms } \\
\text { after the "Go } \\
\text { sustainable" } \\
\text { scenario }\end{array}$ & 20 & 0 & 676 & 589 & 320 & 2970 & 443 & 318 & 5336 \\
\hline
\end{tabular}

Table 3: Evolution of the number of farms based on type, the proportion of farm type change

632 and their trajectories of change from the initial cropping system mosaic to the mosaic

633 obtained from the "Go sustainable" scenario. The changes in bold are spatialized in Figure 7.

635 Most farmers growing banana turned their banana farming systems into crop-gardening systems and became either crop-gardeners or diversified farmers. However, specialized cane-

637 growers remained cane-growers throughout Guadeloupe because the energy cane was used for

638 electricity production. The population of orchard growers that changed their specialization in

639 south-western Basse-Terre turned towards livestock breeding. Farming systems in northern

640 Basse-Terre remained almost identical. 


\subsection{A framework to guide the scenario-based integrated analysis of agricultural systems}

644

645

646

647

648

649

650

651

652

653

654

655

656

657

658

659

660

661

662

663

664

665

666

The MOSAICA-f framework can help to parameterize a multi-functional scenario to improve the contributions of agricultural systems at a regional level to several sustainability issues. To achieve this and attain one or several goals, the framework can design scenarios made up of changes to drivers that can optimally modify the agricultural landscapes. Most current scenario analyses only compare business-as-usual scenarios with highly contrasted exploratory scenarios (Kok et al., 2011; Milestad et al., 2014; Vervoort et al., 2014; Gutzler et al., 2015). The set of scenarios produced by these approaches are useful in that they can provide decision-makers with contrasting views regarding the development potentials of the system being modelled (Herrero et al., 2014). However, in the past, we lacked a modelling framework for the iterative design of a multi-functional scenario, achieved through the simultaneous modification of several drivers of change. We propose such a framework based on the development of multi-functional scenarios and achieved by combining exploratory, normative and optimized scenarios across our 5-step method. The exploratory approach used (step 3) after the optimized approach (step 2) mimics the backward approach used in scenario analysis (van Vliet et al., 2012; Borjeson et al., 2006, Quist et al., 2011; Kok et al., 2011) to show how visions of the future and goals that are generated under an optimized scenario could be met (Ramos, 2010). Normative scenarios (step 4) indicate whether the agricultural systems can or cannot achieve these regional goals, and exploratory scenarios are helpful when selecting a set of drivers to meet these goals. For each goal, the targets defined with the optimized scenarios can provide information on the structural gap between the reference cropping system mosaic and the optimal cropping system mosaic for a given sustainability issue (Acosta-Alba et al., 2012; Bryan et al., 2011). Targets are often thresholds that must be attained and their definition is based on expert knowledge when this is available. In our test 
case, targets were not available for each domain; thus, the optimized scenario was used to provide information regarding potential development of the reference landscape mosaic. This combination of scenarios is possible at the regional scale because the MOSAICA model allows for the optimisation of indicators and the change of constraints at the regional scale. This is not possible using regional approaches where models are run at the farm scale and the results are then up-scaled to the regional level.

In step 5 of the framework, the combination of drivers aims to design a scenario that can make use of the potential synergies between drivers, meaning that the combined impact will exceed the sum of their individual impacts. Use of the framework with a single driver was implemented first of all in order to identify drivers of interest, and then combine them to identify potential coherence among drivers of change. We have focused here on designing scenarios under which we can account for interactions between drivers in order to maximise their ability to improve their contribution to issues. This type of framework is similar to that used in multi-objective studies, in which several system variables are optimized to assess the potential contribution of the model to several sustainability issues (Acosta-alba et al., 2012, Groot et al., 2012). However, the objectives need to be prioritized when using this type of approach, which introduces subjectivity when analysing impacts. Lastly, the results of our framework could be improved by modifying the MOSAICA model to become a dynamic (e.g. recursive) model that could operate the transition from a reference agricultural landscape to one generated under the "go sustainable" scenario (Janssen and van Ittersum, 2007).

\subsection{Spatially explicit multi-scale analysis}

One specific feature of the MOSAICA-f framework is that it can be used to test a broad range of drivers at different spatial scales with spatially explicit drivers and outcomes. The drivers 
thus tested are new agricultural policies (e.g. change of subsidies), change of social context (e.g. changes of diet, with more consumption of local agricultural products) and new cropping system characteristics (e.g. organic cropping systems). Others drivers could have been selected, such as biophysical (e.g. remodelling of field slope), environmental (e.g. zones with a restricted use of pesticides), or social (e.g. change in land tenure) drivers. They could have been implemented at the field, farm, sub-regional and regional scales, and specifically targeted certain fields, farms or sub-regions. Thus, in our pathway for scenario building, we mixed different drivers (such as new cropping system characteristics) with either new cropping systems (e.g., organic crop-gardening and energy crops) or improved cropping systems (e.g., crop-gardening with reduced gross margin variability) at the field scale, social context changes at the regional scale (e.g., increased availability of labour), new agricultural policies (changes of market size thresholds based on local consumption), new agricultural policies at the sub-regional scale (e.g., banning the cultivation of food crops on polluted soils) or the regional scale (e.g., cessation of subsidies for sugar production). This type of multiscale and spatially targeted strategy is relevant when responding to local and global issues (e.g., food self-sufficiency (Spiertz et al., 2012), biodiversity (Cunningham et al., 2013) and climate change (Lyle, 2015). Hence MOSAICA can be of use when trying to find solutions to global and local challenges related to agriculture.

This framework may be of particular use to inform regional planning because it generates optimal outcomes at the regional scale and provides information on the spatial organization of crops and its impacts at different spatial scales. Building multi-functional agricultural landscapes implies significant changes to agricultural systems across several scales, driving transitions in cropping and farming systems (Seppelt et al., 2013). Such agricultural system transitions must be accompanied by several political, technical and agronomic prerequisites. 
Agricultural policies can provide subsidies that enable changes to farming systems. Changes to farming practices require financial and technical support for farmers, including the supply of new equipment (e.g., for irrigation or mechanical tillage) and training so that farmers can manage more complex cropping systems. Increases in local food consumption are linked with education policies and local consumers' willingness to pay for local food crops (Barlagne et al., 2015). This spatially explicit information on changes to agriculture impacts, displayed in the form of maps, can guide decision-makers when implementing spatially targeted measures that are likely to be more efficient than regional policies. We therefore hypothesize that the MOSAICA-f framework could be a useful tool for policy analysis and design at the regional level if it is properly used in interaction with decision-makers (Delmotte et al., 2016), although that is beyond the scope of our work.

\subsection{Framework implementation with decision-makers}

The MOSAICA-f framework could help decision makers by providing knowledge on drivers towards a better contribution to the sustainable development of a region. However, the MOSAICA framework requires a well-adapted interaction between modellers and stakeholders, including decision-makers, to fulfil these sustainability objectives. Participatory modelling with optimization tools requires particular attention because parameterization of the different scenarios within the model, and simulation, require large amounts of time (Delmotte et al., 2016). Because of this time requirement, decision-makers and modellers need to manage the framework together. Nevertheless the scientific and modelling skills required to ensure appropriate use of the MOSAICA model for scenario simulation implies that both the modelling component and the overall 5-step approach are managed by a multidisciplinary group of scientists. This group should i) have wide-ranging knowledge of cropping system performance, farm function and impact assessment and ii) have the 
programming skills required to modify the MOSAICA model for each type of scenario.

Decision-makers need to participate actively in scenario design and the diagnosis and definition of the issues they want to address (Walz et al., 2007). Co-designing or co-selecting sustainability issues and/or indicators for the contribution of agriculture to sustainable development (Mascarenhas et al., 2015), while considering the variables used and produced by the model; are also important to successful participatory approaches (Therond et al., 2009). Meetings with decision-makers should be organized by the modelling team and local experts in order to exchange possible drivers of local agriculture changes so as to target relevant drivers of changes to farming systems. A range of values to be tested for each driver needs to be defined. The modellers should then run the simulation of the different scenarios and present their results to decision-makers. Feedback from decision-makers should integrate the new drivers that emerged from group thinking (e.g. brainstorming) with the range of values to be tested. This loop between decision-makers and modellers could operate continuously as the model integrates new sustainability issues (e.g., crop diseases) and indicators with a broader diversity of cropping systems or the addition of new fields within the field characteristics database.

An analysis of the sensitivity of model outputs to model inputs or the drivers tested under the exploratory scenarios would also be important prerequisites for stakeholder discussions on the scenarios presented in this paper. Sensitivity analysis could be used in two ways: i) to assess the impacts of input variable uncertainty on the framework outputs, and ii) to refine the analysis of a given scenario by assessing the impacts of driver values on scenario outcomes. The former specifically targets the uncertainty in the model inputs from calibration of the model, such as the technical coefficients that define cropping systems. The outcomes of this use regarding the uncertainty of indicator values must be discussed with decision makers in 
order to determine whether it can fit into their decision process or to convince them to invest in data acquisition and/or model development so as to reduce uncertainty. The latter use would focus on how, and to what extent, a particular driver can help to attain a target value and improve the contribution of agriculture to sustainable development. Different driver values should be tested step by step to identify which has the best potential effect in terms of multi-functionality in the post-modelling components. The Morris method could be used for this sensitivity analysis because it i) is a reliable technique to identify and rank important variables in terms of their impacts on the output variability of a modelled system (DeJonge et al., 2012; Drouet et al., 2011), and ii) is well-adapted to analyze a combination of variables, such as the combination of drivers tested within our framework.

\section{Conclusions}

In this paper, we have proposed and tested a model-based framework for the design and assessment of multi-functional agricultural landscapes. This framework is based on five steps that enable the construction of sustainable cropping system mosaics using a bioeconomic model. This framework combines optimized, normative and exploratory scenarios to provide knowledge to decision-makers regarding the potential drivers of change that could be used to attain multiple local and global sustainability goals. This holistic approach offers an analysis of the changes and impacts that could or should occur at the regional, farm and field scales, and highlights the spatial externalities of cropping system mosaics. This framework could be used to study potential spatial trade-offs between the provision of services by agriculture to society by means of spatialized indicators, as was done by Tian et al. (2015) at a watershed scale. In addition, the results of this study show that it is important to account for spatial heterogeneity in regional studies, and also to consider multiple drivers when the aim is to achieve multi-functional agriculture. This proposed framework could help decision makers, 
795

796

797

798

799

800

801

802

803

804

805

806

807

808

809

810

811

812

813

814

815

farmers and society understand the pathways needed to achieve transition towards a more

sustainable future in regions where significant investments are made in data acquisition at the field, farm and regional scales.

\section{References}

Acosta-Alba, I., Lopez-Ridaura, S., van der Werf, H.M.G., Leterme, P., Corson, M.S., 2012.

Exploring sustainable farming scenarios at a regional scale : an application to dairy farms in Brittany. Journal of Cleaner Production 28, 160-167. doi:10.1016/j.jclepro.2011.11.061

Agreste, 2011. Premières tendances. N²70. Novembre 2011 (2011).

http://agreste.agriculture.gouv.fr/IMG/pdf_D97111A02.pdf (Accessed 21 March 2014)

Arfini, F., 2005. Modelling agricultural policies: state of the art and new challenges.

Proceedings of the 89th EAAE Seminar. February 3-5, 2005, Parma

Barlagne, C., Bazoche, P., Thomas, A., Ozier-Lafontaine, H., Causeret, F.o., Blazy, J.-M., 2015. Promoting local foods in small island states: The role of information policies. Food Policy 57. 62-72. doi: http://dx.doi.org/10.1016/j.foodpol.2015.09.003

Belhouchette, H., Louhichi, K., Therond, O., Mouratiadou, I., Wery, J., Ittersum, M.v.,

Flichman, G., 2011. Assessing the impact of the Nitrate Directive on farming systems using a bio-economic modelling chain. Agricultural Systems 104, 135-145.

doi:10.1016/j.agsy.2010.09.003 
Benoît, M., Rizzo, D., Marraccini, E., Moonen, A., Galli, M., Lardon, S., Rapey, H., Thenail, C., Bonari, E., 2012. Landscape agronomy: a new field for addressing agricultural landscape dynamics. Landscape Ecology 27 (10),1385-1394. doi: 10.1007/s10980-012-9802-8

Borjeson, L., Hojer, M., Dreborg, K.-H., Ekvall, T., Finnveden, G., 2006. Scenario types and techniques: Towards a user's guide. Futures 38, 723-739. Doi: 10.1016/j.futures.2005.12.002

Bryan, B.A., Crossman, N.D., King, D., Meyer, W.S., 2011.Landscape futures analysis:

Assessing the impacts of environmental targets under alternative spatial policy options and future scenarios. Environmental Modelling \& Software 26, 83-91.

doi:10.1016/j.envsoft.2010.03.034

Cabidoche, Y.-M., Lesueur-Jannoyer, M., 2012. Contamination of Harvested Organs in Root Crops Grown on Chlordecone-Polluted Soils. Pedosphere 22 (4), 562-574. doi:10.1016/S1002-0160(12)60041-1

Carmichael, J., Tansey, J., Robinson, J., 2004. An integrated assessment modeling tool. Global Environmental Change 14, 171-183. doi : http://dx.doi.org/10.1016/j.gloenvcha.2003.12.002

Carof, M., Colomb, B., Aveline, A., 2013. A guide for choosing the most appropriate method for multi-criteria assessment of agricultural systems according to decision-makers' expectations. Agricultural Systems 115, 51-62. doi: http://dx.doi.org/10.1016/j.agsy.2012.09.011 
852

853

Castellazzi, M.S., Matthews, J., Angevin, F., Sausse, C., Wood, G.A., Burgess, P.J., Brown, I., Conrad, K.F., Perry, J.N., 2010. Simulation scenarios of spatio-temporal arrangement of crops at the landscape scale. Environmental Modelling \& Software 25, 1881-1889.doi :

10.1016/j.envsoft.2010.04.006

Chopin, P., Blazy, J.-M., Doré, T., 2015a. A new method to assess farming system evolution at the landscape scale. Agronomy for Sustainable Development 35, 325-337. doi :10.1007/s13593-014-0250-5

Chopin, P., Doré, T., Guindé, L., Blazy, J.-M., 2015b. MOSAICA: A multi-scale bioeconomic model for the design and ex ante assessment of cropping system mosaics. Agricultural Systems 140, 26-39. doi: http://dx.doi.org/10.1016/j.agsy.2015.08.006

Cunningham, S.A., Attwood, S.J., Bawa, K.S., Benton, T.G., Broadhurst, L.M., Didham, R.K., McIntyre, S., Perfecto, I., Samways, M.J., Tscharntke, T., Vandermeer, J., Villard, M.A., Young, A.G., Lindenmayer, D.B., 2013. To close the yield-gap while saving biodiversity will require multiple locally relevant strategies. Agriculture, Ecosystems \& Environment 173, 20-27. doi:10.1016/j.agee.2013.04.007

Dale, V., Kline, K., Kaffka, S., Langeveld, J.W.A., 2013. A landscape perspective on sustainability of agricultural systems. Landscape Ecology 28, 1111-1123. doi : $10.1007 / \mathrm{s} 10980-012-9814-4$

DeJonge, K.C., Ascough Ii, J.C., Ahmadi, M., Andales, A.A., Arabi, M., 2012. Global sensitivity and uncertainty analysis of a dynamic agroecosystem model under different 
865

866

867

868

869

870

871

872

873

874

875

876

877

878

879

880

881

882

883

884

885

886

887

888

889

irrigation treatments. Ecological Modelling 231, 113-125. doi:

http://dx.doi.org/10.1016/j.ecolmodel.2012.01.024

Delmotte, S., Lopez-Ridaura, S., Barbier, J.-M., Wery, J., 2013. Prospective and participatory integrated assessment of agricultural systems from farm to regional scales: Comparison of three modeling approaches. Journal of Environmental Management 129, 493-502. doi:

10.1016/j.jenvman.2013.08.001

Delmotte S., J.M Barbier, J.C Mouret, C. Le Page, J. Wery, P. Chauvelon, A. Sandoz, S. Lopez Ridaura, 2016. Participatory integrated assessment of scenarios for organic farming at different scales in Camargue, France. Agricultural Systems 143: 147-158. http://dx.doi.org/10.1016/j.agsy.2015.12.009.

Drouet, J.L., Capian, N., Fiorelli, J.L., Blanfort, V., Capitaine, M., Duretz, S., Gabrielle, B., Martin, R., Lardy, R., Cellier, P., Soussana, J.F., 2011. Sensitivity analysis for models of greenhouse gas emissions at farm level. Case study of N2O emissions simulated by the CERES-EGC model. Environmental Pollution 159, 3156-3161. doi:

http://dx.doi.org/10.1016/j.envpol.2011.01.019

Ewert, F., van Ittersum, M.K., Heckelei, T., Therond, O., Bezlepkina, I., Andersen, E., 2011.

Scale changes and model linking methods for integrated assessment of agri-environmental systems. Agriculture Ecosystems \& Environment 142, 6-17. doi: 10.1016/j.agee.2011.05.016

FAOSTAT, 2008. Food and Agriculture Organization of the United Nations, FAOSTAT database available at http://faostat.fao.org/site/362/DesktopDefault.aspx?PageID=362. 
891 Florin, M.J., van Ittersum, M.K., van de Ven, G.W.J., 2013. Family farmers and biodiesel 892 production: Systems thinking and multi-level decisions in Northern Minas Gerais, Brazil.

893

894

895

896

897

898

899

900

901

902

903

904

905

906

907

908

909

910

911

912

913

914

Agricultural Systems 121, 81-95. http://dx.doi.org/10.1016/j.agsy.2013.07.002

Gafsi, M., Legagneux, B., Nguyen, G., Robin, P., 2006. Towards sustainable farming systems: Effectiveness and deficiency of the French procedure of sustainable agriculture. Agricultural Systems 90, 226-242. doi: http://dx.doi.org/10.1016/j.agsy.2006.01.002

Gerdessen, J.C., Pascucci, S., 2013. Data Envelopment Analysis of sustainability indicators of European agricultural systems at regional level. Agricultural Systems 118, 78-90. doi: http://dx.doi.org/10.1016/j.agsy.2013.03.004.

Groot, J.C.J., Rossing, W.A.H., Jellema, A., Stobbelaar, D.J., Renting, H., Van Ittersum, M.K., 2007. Exploring multi-scale trade-offs between nature conservation, agricultural profits and landscape quality: A methodology to support discussions on land-use perspectives.

Agriculture, Ecosystems \& Environment 120, 58-69. doi:

http://dx.doi.org/10.1016/j.agee.2006.03.037

Groot, J.C.J., Oomen, G.J.M., Rossing, W.A.H., 2012. Multi-objective optimization and design of farming systems. Agricultural Systems 110, 63-77. doi :

http://dx.doi.org/10.1016/j.agsy.2012.03.012

Gutzler, C., Helming, K., Balla, D., Dannowski, R., Deumlich, D., Glemnitz, M., Knierim, A., Mirschel, W., Nendel, C., Paul, C., Sieber, S., Stachow, U., Starick, A., Wieland, R., Wurbs, 
A., Zander, P., 2015. Agricultural land use changes- a scenario-based sustainability impact assessment for Brandenburg, Germany. Ecological Indicators 48, 505-517. doi:10.1016/j.ecolind.2014.09.004

Heckelei, T., and W. Britz (2001): Concept and Explorative Application of an EU-wide Regional Agricultural Sector Model (CAPRI-Project). In: Heckelei, T., H.P. Witzke, and W. Henrichsmeyer (Eds.): Agricultural Sector Modelling and Policy Information Systems. Proceedings of the 65th EAAE Seminar, March 29-31, 2000 at Bonn University, Vauk Verlag Kiel

Herrero, M., Thornton, P.K., Bernués, A., Baltenweck, I., Vervoort, J., van de Steeg, J., Makokha, S., van Wijk, M.T., Karanja, S., Rufino, M.C., Staal, S.J., 2014. Exploring future changes in smallholder farming systems by linking socio-economic scenarios with regional and household models. Global Environmental Change 24, 165-182. doi:10.1016/j.gloenvcha.2013.12.008

Houet, T., Schaller, N., Castet, M., Gaucherel, C., 2014. Improving the simulation of fineresolution landscape changes by coupling top-down and bottom-up land use and cover changes rules. International Journal of Geographical Information Science 28 (9), 1848-1876.

INSEE, 2012. Enquête Emploi DOM 2012. http://www.insee.fr/fr/themes/ document.asp?ref_id=19216. Accessed on the 5th May 2014. 
951

952

953

954

955

956

Janssen, S., van Ittersum, M.K., 2007. Assessing farm innovations and responses to policies:

A review of bio-economic farm models. Agricultural Systems 94, 622-636. doi :

10.1016/j.agsy.2007.03.001.

Klapwijk, C.J., van Wijk, M.T., Rosenstock, T.S., van Asten, P.J.A., Thornton, P.K., Giller, K.E., 2014. Analysis of trade-offs in agricultural systems: current status and way forward. Current Opinion in Environmental Sustainability 6, 110-115. doi : http://dx.doi.org/10.1016/j.cosust.2013.11.012.

Kok, K., van Vliet, M., Baerlund, I., Dubel, A., Sendzimir, J., 2011. Combining participative backcasting and exploratory scenario development: Experiences from the SCENES project. Technological Forecasting and Social Change 78, 835-851.doi:

10.1016/j.techfore.2011.01.004

Kropff, M.J., Bouma, J., Jones, J.W., 2001. Systems approaches for the design of sustainable agro-ecosystems. Agricultural Systems 70, 369-393. doi: http://dx.doi.org/10.1016/S0308$521 X(01) 00052-X$

Louhichi, K., Kanellopoulos, A., Janssen, S., Flichman, G., Blanco, M., Hengsdijk, H., Heckelei, T., Berentsen, P., Lansink, A.O., Van Ittersum, M., 2010. FSSIM, a bio-economic farm model for simulating the response of EU farming systems to agricultural and environmental policies. Agricultural Systems 103, 585-597.doi : 10.1016/j.agsy.2010.06.006 
964

979

Lyle, G., 2015. Understanding the nested, multi-scale, spatial and hierarchical nature of future climate change adaptation decision making in agricultural regions: A narrative literature review. Journal of Rural Studies 37, 38-49. doi:10.1016/j.jrurstud.2014.10.004

Mascarenhas, A., Ramos, T.s.B., Haase, D., Santos, R., 2015. Ecosystem services in spatial planning and strategic environmental assessment - A European and Portuguese profile. Land use policy 48, 158-169. doi:10.1016/j.landusepol.2015.05.012

Meyer, R., 2007. Comparison of scenarios on futures of European food chains. Trends in Food Science \& Technology 18, 540-545. doi: 10.1016/j.tifs.2007.02.008

Milestad, R., Svenfelt, Ã.s., Dreborg, K.H., 2014. Developing integrated explorative and normative scenarios: The case of future land use in a climate-neutral Sweden. Futures 60. 5971. doi: http://dx.doi.org/10.1016/j.futures.2014.04.015

Multigner, L., Ndong, JR., Giusti, A., Romana, M., Delacroix-Maillard, H., Cordier, S., Jégou, B., Thome, JP., Blanchet, P., 2010. Chlordecone exposure and risk of prostate cancer. Journal of Clinical Oncology 28(21),3457-62. doi: 10.1200/JCO.2009.27.2153.

Parra-Lopez, C., Calatrava-Requena, J., de-Haro-Gimenez, T., 2008. A systemic comparative assessment of the multifunctional performance of alternative olive systems in Spain within an AHP-extended framework. Ecological Economics 64, 820-834.doi : 10.1016/j.ecolecon.2007.05.00 
PDRG (Programme de. Développement Rural de la. Guadeloupe), 2011.. TOME 1. Données generals. V4-Tome 1-etat des lieux et stratégie-sept2011. 1/76. (2011). http://agriculture.gouv.fr/IMG/pdf/PDRG_V4_Tome1.pdf (Accessed 24 December 2014)

POSEI, 2012. Programme portant sur les mesures spécifiques dans le domaine de l'agriculture en faveur des régions ultrapériphériques. Tome 1. Chapitre 1 à 3. Version 2012 applicable à partir du 01 janvier 2012. Décision d'exécution C(2012) 115 du 20 janvier 2012. http://www.odeadom.fr/wp-content/uploads/2012/03/posei-france-2012_vf_toustomes.pdf. Date de consultation : 10/09/14.

Quist, J., Thissen, W., Vergragt, P.J., 2011. The impact and spin-off of participatory backcasting: From vision to niche. Technological Forecasting and Social Change 78, 883-897. doi:10.1016/j.techfore.2011.01.011.

\section{Ramos, I.L., 2010. 'Exploratory landscape scenarios' in the formulation of 'landscape quality} objectives'. Futures 42, 682-692. doi: http://dx.doi.org/10.1016/j.futures.2010.04.005

Riesgo, L., Gomez-Limon, J.A., 2006. Multi-criteria policy scenario analysis for public regulation of irrigated agriculture. Agricultural Systems 91, 1-28. doi :

10.1016/j.agsy.2006.01.005

Sadok, W., Angevin, F., Bergez, J.-E., Bockstaller, C., Colomb, B., Guichard, L., Reau, R., Dore, T., 2008. Ex ante assessment of the sustainability of alternative cropping systems: implications for using multi-criteria decision-aid methods. A review. Agronomy for Sustainable Development 28, 163-174. doi :10.1051/agro:2007043 
farmers' decision rules and landscape stochastic regularities for landscape modelling.

Sepp, K., Bastian, O., 2007. Studying landscape change: Indicators, assessment and application. Landscape and Urban Planning 79, 125-126. doi: http://dx.doi.org/10.1016/j.landurbplan.2006.02.002

1018

Seppelt, R., Lautenbach, S., Volk, M., 2013.Identifying trade-offs between ecosystem services, land use, and biodiversity: a plea for combining scenario analysis and optimization on different spatial scales. Current Opinion in Environmental Sustainability 5, 458-463. doi:10.1016/j.cosust.2013.05.002

Schönhart, M., Schauppenlehner, T., Schmid, E., Muhar, A., 2011. Integration of bio-physical and economic models to analyze management intensity and landscape structure effects at farm and landscape level. Agricultural Systems 104, 122 - 134. doi:10.1016/j.agsy.2010.03.014

Spiertz, H., 2012. Avenues to meet food security. The role of agronomy on solving complexity in food production and resource use. European Journal of Agronomy 43, 1-8. doi:10.1016/j.eja.2012.04.004 typical Karst Watershed, SW China. Science of the Total Environment, in press. http://dx.doi.org/10.1016/j.scitotenv.2016.05.190 
Tillieut, O., Cabidoche, Y.-M., 2006.Cartographie de la pollution des sols de Guadeloupe par la chlordécone : Rapport technique. DAAF-SA \& INRA-ASTRO, Abymes, 23p.

1038

Tilman, D., Cassman, K.G., Matson, P.A., Naylor, R., Polasky, S., 2002. Agricultural

sustainability and intensive production practices. Nature 418, 671-677.

doi:10.1038/nature01014

1042

1043

Therond, O., Belhouchette, H., Janssen, S., Louhichi, K., Ewert, F., Bergez, J.-E., Wery, J.,

Heckelei, T., Olsson, J.A., Leenhardt, D., Van Ittersum, M., 2009. Methodology to translate

policy assessment problems into scenarios: the example of the SEAMLESS integrated

framework. Environmental Science \& Policy 12, 619-630. doi : 10.1016/j.envsci.2009.01.013

1047

1048

van Ittersum, M.K., Donatelli, M., 2003. Modelling cropping systems: highlights of the

symposium and preface to the special issues. European Journal of Agronomy 18, 187-197

doi:10.1016/S1161-0301(02)00095-3

1051

1052

van Ittersum, M.K., Ewert, F., Heckelei, T., Wery, J., Alkan Olsson, J., Andersen, E.,

1053

Bezlepkina, I., Brouwer, F., Donatelli, M., Flichman, G., Olsson, L., Rizzoli, A.E., van der

1054

1055

1056

Wal, T., Wien, J.E., Wolf, J., 2008. Integrated assessment of agricultural systems: A

component-based framework for the European Union (SEAMLESS). Agricultural Systems

96, 150-165. doi:10.1016/j.agsy.2007.07.009

1057

1058

van Notten, P.W.F., Rotmans, J., van Asselt, M.B.A., Rothman, D.S., 2003. An updated

1059

scenario typology. Futures 35, 423-443. doi: 10.1016/s0016-3287(02)00090-3 
van Vliet, M., Kok, K., Veldkamp, A., Sarkki, S., 2012. Structure in creativity: An exploratory

Verburg, P.H., Veldkamp, A., Rounsevell, M.D.A., 2006. Scenario-based studies of future land use in Europe. Agriculture Ecosystems \& Environment 114, 1-6. doi : 10.1016/j.agee.2005.11.023

1068

Vervoort, J.M., Thornton, P.K., Kristjanson, P., Förch, W., Ericksen, P.J., Kok, K., Ingram,

J.S.I., Herrero, M., Palazzo, A., Helfgott, A.E.S., Wilkinson, A., Havlík, P., Mason-D’Croz,

D., Jost, C., 2014. Challenges to scenario-guided adaptive action on food security under climate change. Global Environmental Change 28, 383-394. doi:

1073 http://dx.doi.org/10.1016/j.gloenvcha.2014.03.001

1074 model-based study. Agricultural Systems 83, 179-202. doi :

1078 http://dx.doi.org/10.1016/j.agsy.2004.03.006

1079

Walz, A., Lardelli, C., Behrendt, H., Gret-Regamey, A., Lundstrom, C., Kytzia, S., Bebi, P., 2007. Participatory scenario analysis for integrated regional modelling. Landscape and Urban Planning 81, 114-131. doi: 10.1016/j.landurbplan.2006.11.001 
1084 Walz, U., 2015. Indicators to monitor the structural diversity of landscapes. Use of ecological 1085 indicators in models, Ecological modelling 295. 88-106. doi:

1086 http://dx.doi.org/10.1016/j.ecolmodel.2014.07.011

1087

1088 Wei, Y., Davidson, B., Chen, D., White, R., 2009. Balancing the economic, social and 1089 environmental dimensions of agro-ecosystems: An integrated modeling approach. Agriculture, 1090 Ecosystems \& Environment 131, 263-273.doi : http://dx.doi.org/10.1016/j.agee.2009.01.021 1091 

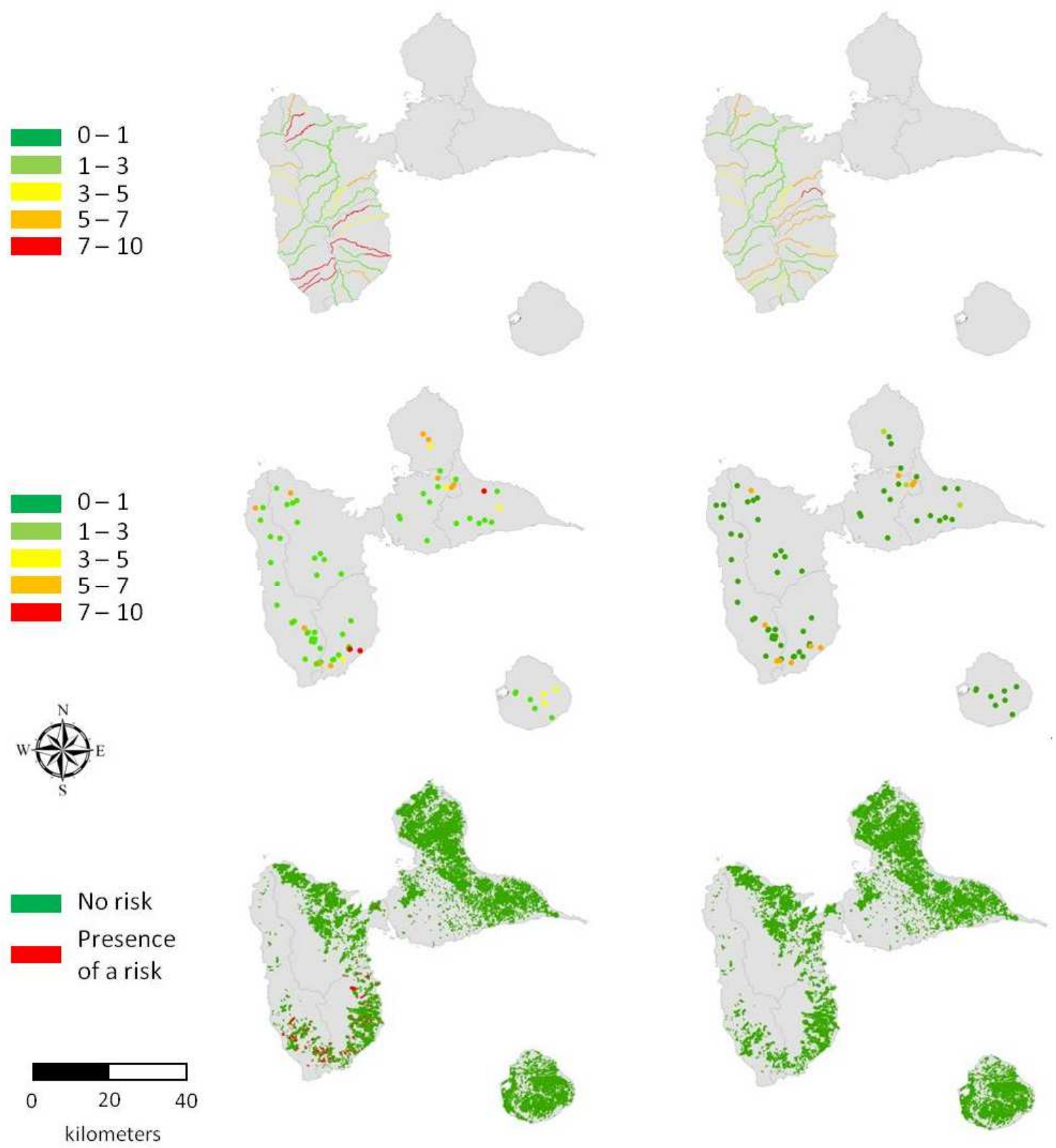

Figure A: Comparison of the evolution of the contribution of cropping system mosaics to the 1095 decrease of pollution in rivers (top), drinking-water abstraction (middle) and to the decrease 1096 of the area of risk of contamination of crops by chlordecone (bottom) between the current 1097 mosaic (left) and the one from the "Go sustainable" scenario (right). 


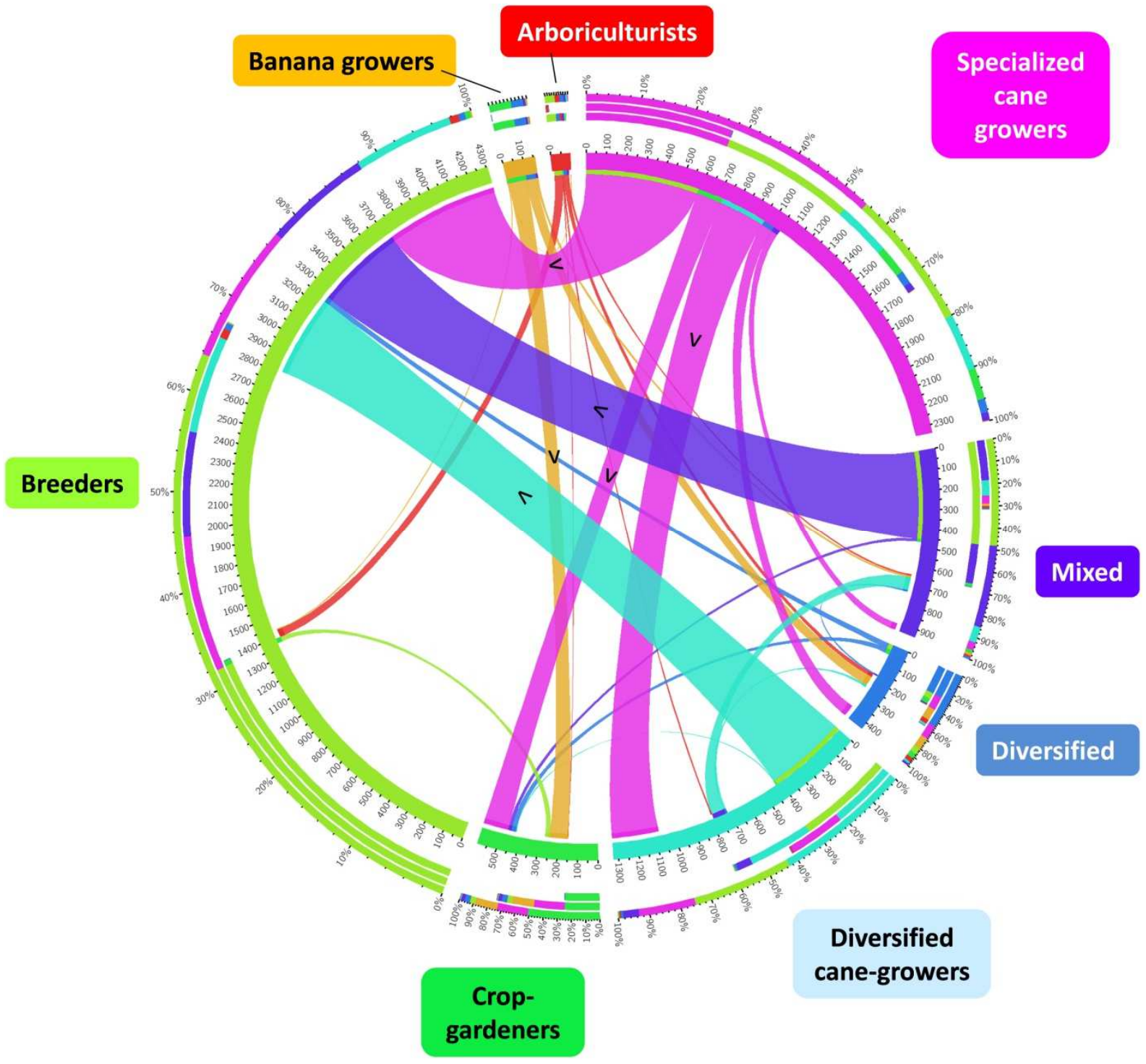

1100 Figure B: Trajectories of farming system changes within the territory. Arrows represent

1101 the directions of farming system changes from the initial to the "Go sustainable" mosaic.

1102 Ribbons between types represent the transition of farms from a given type in the initial

1103 cropping system mosaic to another one in the mosaic obtained with the "Go sustainable"

1104 scenario. Ribbon width represents the number of farms in transition. The angular sizes of

1105 circularly arranged segments represent the population of each type and are proportional to the

1106 size of farm types in the initial cropping system mosaic. The four circularly arranged stake

1107 bars, from the center of the figure to the edges, represent respectively, the relative contribution 
1108 of outgoing ribbons from each farm type in number of farms, in percentage, the relative

1109 contribution of ingoing ribbons to each farm type in percentage and the proportion of ingoing 1110 and outgoing ribbons in the total population.

1111 